\title{
LONG-TERM EFFECT OF ORGANIC AND CONVENTIONAL FARMING PRACTICES ON MICROBIAL BIOMASS CARBON, ENZYME ACTIVITIES AND MICROBIAL POPULATIONS IN DIFFERENT TEXTURED SOILS OF HARYANA STATE (INDIA)
}

\author{
SHEORAN, H. S. $.^{*}-$ PHOGAT, V. K. ${ }^{1}-$ DAHIYA, R. ${ }^{1}-$ GERA, R. ${ }^{2}$ \\ ${ }^{1}$ Department of Soil Science, CCS Haryana Agricultural University \\ Hisar, Haryana 125004, India \\ ${ }^{2}$ Department of Microbiology, CCS Haryana Agricultural University \\ Hisar, Haryana 125004, India \\ *Corresponding author \\ e-mail: sheoranhardeep2008@gmail.com \\ (Received $7^{\text {th }}$ Feb 2018; Accepted $9^{\text {th }}$ May 2018)
}

\begin{abstract}
The aim of the present study was to evaluate the impact of management practices on soil biological properties of texturally different soils of Haryana. Surface soil samples were collected from 25 organic farms and their adjoining conventional farms at 11 districts of Haryana and assayed for microbial biomass carbon (MBC), dehydrogenase and phosphatase activities along with total bacterial, actinomycetes and fungi populations in soil. The overall dehydrogenase and phosphatase activities at different locations were found to increase from 35.3 to $56.1 \mu \mathrm{g} \mathrm{TPF} \mathrm{g}{ }^{-1}$ soil $24 \mathrm{hr}^{-1}$ and from 275.8 to $364.1 \mu \mathrm{g} \mathrm{PNP} \mathrm{g}^{-1}$ soil, respectively under organic farming i.e. an increase of 57.5 and $32.01 \%$. Overall a significantly higher MBC $(69.1 \%)$ was observed under organically managed soils $\left(274 \mathrm{mg} \mathrm{kg}^{-1}\right)$ compared to conventional $\left(162 \mathrm{mg} \mathrm{kg}^{-1}\right)$. The total bacterial, fungal and actinomycetes counts increased by $56.9,55.2$ and $49.5 \%$, respectively, in comparison to those in the conventionally managed soils. The study concluded that soils under organic farming were found to be superior in terms of biological properties than conventionally managed soils which are essential for enhancing soil production and other functions in the given ecosystem.
\end{abstract}

Keywords: management practices, microbial growth, organic farming, soil quality

\section{Introduction}

Land management practices in present day agriculture are getting more and more important where food grain production and fertilizer use run parallel to meet the food requirements of over increasing population of India and leading to over exploitation of our natural resources like soil and water and therefore, soil is degrading day by day with respect to its fertility and productivity. This may be attributed to the fact that removal of nutrient resources from the soil strata is higher than their replenishment, so soil is becoming deficient in major available macro and micronutrients, which consequently leads to the decline of organic matter in soil and the overuse of chemical fertilizers and pesticides are adversely affecting the ecosystem (Yang et al., 2000). Thus, most soils are far from being ideal in fertility and should therefore be improved only by adopting appropriate management practices which includes amendments, like organic manures for enhancing the activity of "soil life". Enzymes and microorganisms like bacteria, actinomycetes and fungi present in soil are sensitive to changing soil environment and hence are considered to be one of the best soil health indicators. These microbes found to have direct role in sustaining soil fertility and its production by playing a crucial role in transformation of various nutrients and thereby improving the soil functioning in a 
given ecosystem. Thus, the study of the microbes and responses of enzymatic activities to disturbing agricultural activities is vital to understand how management practices contribute to sustaining soil fertility and productivity to improve soil (Wardle et al., 1999). Microbial populations and their activity are of immense importance in maintaining or sustaining soil health. Providing habitat and transformation of nutrients are complex processes brought about by succession of different micro-organisms in the soil which affect the soil fertility and over use of pesticides in conventional farming may inhibit these vital processes (Baum et al. 2003; Jolankai et al., 2006). Moreover, when soil applied pesticides fail to reach the target, they affect adjacent ecosystems through leaching or aerial drift affecting the diversity and abundance of non-targeted microorganisms causing negative effects on ecosystem processes and trophic interactions (Pimentel and Edwards, 1982). Different land management practices and continuous cultivation without any addition to soils are imposing variations in organic matter levels of soils and subsequent loss of soil organic carbon from the fields under intensive agricultural practices and leads to the alteration of microbial biomass (Srivastava and Singh, 1989). Therefore, there is a growing intention among farmers and researchers to adopt alternative farming practices that enhance or improve the biological properties of soils and thereby sustain soil health and productivity. Among different farming systems, organic farming is popular and its adoption level is increasing day by day to achieve the target of sustainability. In India, it has been estimated that cultivated area under certified organic farming has grown almost 17 fold in the last decade (0.042 mha in 2003-04 to $1.49 \mathrm{mha}$ in 2016-17). The State of Haryana, one of the major agriculture based state of the country situated in the NCR region. It has about 4000 ha of land under organic farming (Anonymous, 2016). The key characteristics of organic farming include protecting the long-term fertility of soils by maintaining organic matter, fostering soil biological activity, careful mechanical intervention, providing nitrogen self-sufficiency through the use of legumes and biological nitrogen fixation, effective recycling of organic materials including crop residues, livestock wastes and weed, and diseases and pest control relying primarily on crop rotations, natural predators, diversity and resistant varieties. At present, the most optimistic estimates show that about 25-30 percent of nutrient needs can be met by various organic sources. Many researchers reported that in organically managed fields activity of earth worms is higher than in inorganic field (Edwards and Lofty, 1974; Kotcon, 2011; Rai et al., 2014; Velmourougane, 2016). In the biodegradation process, earthworms and microbes work together and produce vermicompost, which provides macro $(\mathrm{N}, \mathrm{P}, \mathrm{K}, \mathrm{Ca}$, and $\mathrm{Mg}$ ) and micro nutrients (Fe, $\mathrm{Mn}, \mathrm{Zn}$, and $\mathrm{Cu}$ ) (Amir and Fouzia, 2011). In organic farming, use of manures and crop residues instead of a synthetic fertilizer is reported to reduce groundwater contamination, improve microbial activity, recycle dairy/poultry wastes, and improve soil properties (Poudel et al., 2002). However, the information regarding the long-term effect of organic farming practices on soil biological properties and its feasibility are very scanty. Keeping in view the above concerns, the present study was planned to evaluate the long-term impact of management practices on soil biological properties like microbial biomass carbon (MBC), dehydrogenase and phosphatase activities along with bacterial, actinomycetes and fungi populations in fields particularly of vegetables and horticultural crops with texturally different soils in Haryana. 


$$
-3671 \text { - }
$$

\section{Materials and Methods}

\section{Study area}

Organic farms under different cropping systems, vegetables and horticultural crops and their adjoining conventional farms were identified at eleven districts of Haryana, namely, Sirsa, Fatehabad, Hisar, Jind, Kaithal, Karnal, Kurukshetra, Ambala, Panchkula, Yamunanagar and Panipat and their soil properties were studied. Locations of different sampling sites are presented in Figure 1. A total of 150 soil samples (three replications) of $0-15 \mathrm{~cm}$ depth were collected from the two types of farming systems, which were pooled to make 50 composite samples and analysed for microbial biomass, dehydrogenase and alkaline phosphatase activity, total bacterial, fungal and actinomycetes counts. The texture of soils varied between sand to clay loam, representing almost all the soil types of the State and is presented in Table 1.

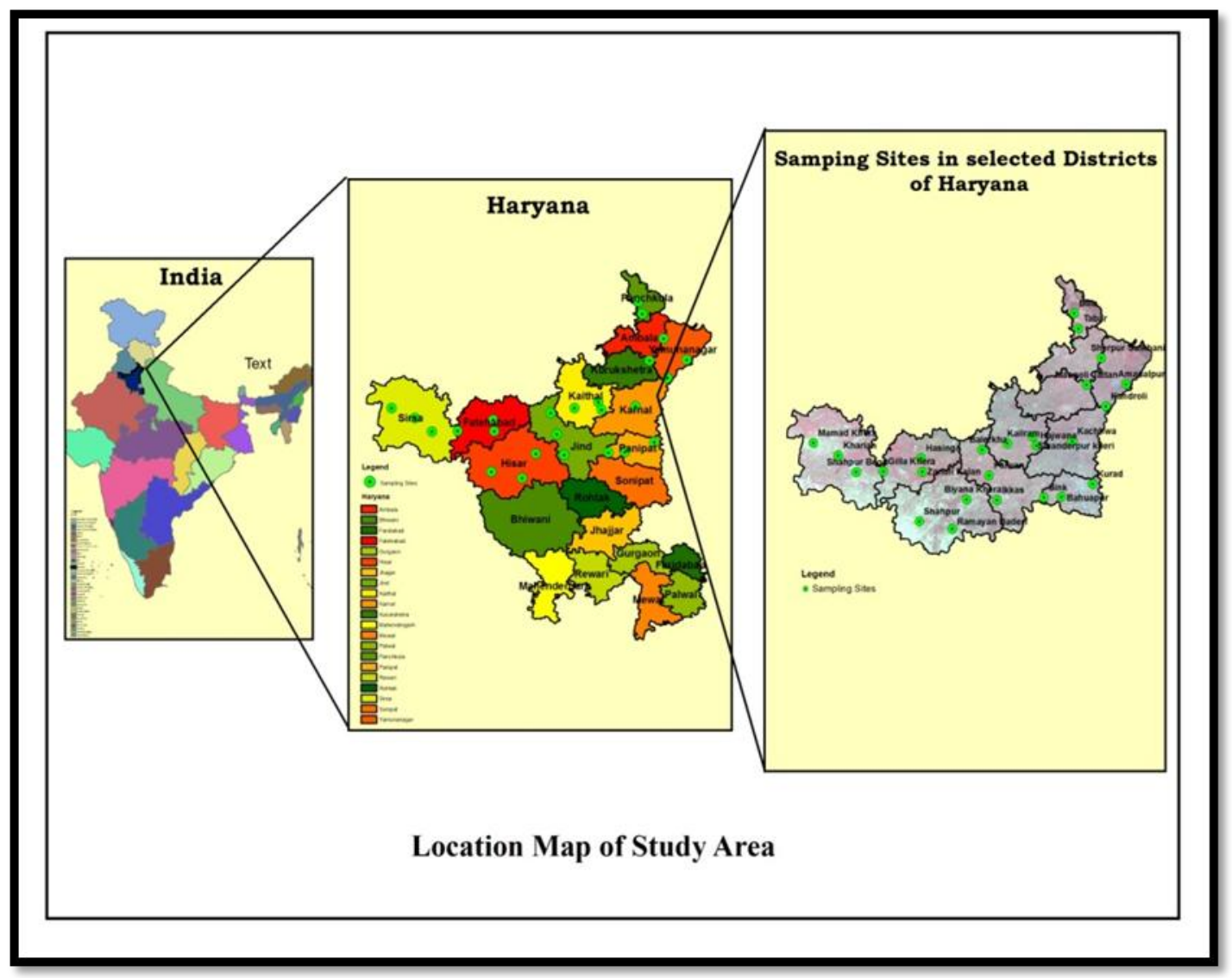

Figure 1. Sampling sites in selected districts of Haryana

\section{Collection of soil samples}

The soil samples collected were representative of the area sampled. A field was treated as a single sampling and recently fertilized fields, bunds, channels, areas near trees, farm ways, buildings, wells, compost piles or other non-representative locations were avoided during sampling. Three soil samples were taken randomly from field and finally one composite sample was prepared. 
Table 1. Soil texture at different locations under conventional and organic farming systems

\begin{tabular}{c|c|c|c}
\hline Location & District & Village & Texture \\
\hline $\mathbf{L}_{\mathbf{1}}$ & Panchkula & Billa & Sand \\
$\mathbf{L}_{\mathbf{2}}$ & Sirsa & Mamad Khera & Sand \\
$\mathbf{L}_{\mathbf{3}}$ & Panipat & Kurad & Loamy sand \\
$\mathbf{L}_{\mathbf{4}}$ & Panchkula & Tabar & Loamy sand \\
$\mathbf{L}_{\mathbf{5}}$ & Sirsa & Kharian & Loamy sand \\
$\mathbf{L}_{\mathbf{6}}$ & Fatehabad & Zandli Kalan & Loamy sand \\
$\mathbf{L}_{\mathbf{7}}$ & Fatehabad & Hasinga & Loamy sand \\
$\mathbf{L}_{\mathbf{8}}$ & Hisar & Shahpur & Loamy sand \\
$\mathbf{L}_{\mathbf{9}}$ & Hisar & Biyana Khera & Sandy loam \\
$\mathbf{L}_{\mathbf{1 0}}$ & Panipat & Bahuapur & Sandy loam \\
$\mathbf{L}_{\mathbf{1 1}}$ & Jind & Ikkas & Sandy loam \\
$\mathbf{L}_{\mathbf{1 2}}$ & Yamunanagar & Amadalpur & Sandy loam \\
$\mathbf{L}_{\mathbf{1 3}}$ & Jind & Balerkha & Loam \\
$\mathbf{L}_{\mathbf{1 4}}$ & Kaithal & Kailram & Loam \\
$\mathbf{L}_{\mathbf{1 5}}$ & Kurukshetra & Mangoli Jattan & Loam \\
$\mathbf{L}_{\mathbf{1 6}}$ & Kaithal & Hajwana & Loam \\
$\mathbf{L}_{\mathbf{1}}$ & Hisar & Ramayan Daderi & Loam \\
$\mathbf{L}_{\mathbf{1 0}}$ & Panipat & Sink & Silt loam \\
$\mathbf{L}_{\mathbf{1 9}}$ & Yamunanagar & Kandroli & Silt loam \\
$\mathbf{L}_{\mathbf{2 0}}$ & Fatehabad & Gilla Khera & Silt loam \\
$\mathbf{L}_{\mathbf{2 1}}$ & Sirsa & Shahpur Begu & Sandy clay loam \\
$\mathbf{L}_{\mathbf{2 2}}$ & Kaithal & Sikanderpur kheri & Sandy clay loam \\
$\mathbf{L}_{\mathbf{2 3}}$ & Jind & Palwan & Clay loam \\
$\mathbf{L}_{\mathbf{2 4}}$ & Karnal & Kachhwa & Clay loam \\
$\mathbf{L}_{\mathbf{2 5}}$ & Ambala & Sherpur Sulkhani & Clay loam \\
\hline
\end{tabular}

\section{Processing of soil samples}

After collection soil samples were kept refrigerated at $0^{\circ} \mathrm{C}$ for analysis of the microbiological properties. Growth media used for the total bacterial, fungal and actinomycetes counts are given in Table 2 .

Table 2. Growth media used for microbial analysis

\begin{tabular}{c|c|c}
\hline Sr. No. & Microbe & Medium \\
\hline 1. & Bacteria & Nutrient Agar \\
2. & Fungi & Potato Dextrose Agar \\
3. & Actinomycetes & Ken-Knight's Medium \\
\hline
\end{tabular}

\section{Soil enzymatic activities}

\section{Dehydrogenase activity}

Dehydrogenase activity was determined by using the method of Casida et al. (1964). Five gram soil was taken and mixed with $3 \%$ solution of 2,3,5-triphenyl tetrazolium chloride and $2.5 \mathrm{ml}$ of distilled water, and incubated for $24 \mathrm{~h}$ at $37^{\circ} \mathrm{C}$ temperature in an incubator. After incubation, $10 \mathrm{ml}$ methanol was added and shaken for 1 minute and filtered through Whatman No. 1 filter paper. The absorbance was measured at $485 \mathrm{~nm}$ by using a spectrophotometer. 


\section{Alkaline phosphatase activity}

Alkaline phosphatase activity was determined by using the method of Tabatabai and Bremner (1969). Enzyme activity was measured by taking $1 \mathrm{~g}$ of soil in a flask and adding $0.2 \mathrm{ml}$ of toluene, $4 \mathrm{ml}$ of modified universal buffer (MUB), $1 \mathrm{ml}$ of $\mathrm{p}$ nitrophenyl phosphate solution to it. After incubating for 1 hour, $1 \mathrm{ml}$ of $0.5 \mathrm{M} \mathrm{CaCl}_{2}$ and $4 \mathrm{ml}$ of $0.5 \mathrm{M} \mathrm{NaOH}$ were added. After stirring for a few seconds, suspension was filtered through Whatman No. 1 filter paper and absorbance of the filtrate was measured at $420 \mathrm{~nm}$ using a spectrophotometer.

\section{Microbial biomass carbon (soil fumigation-extraction method)}

Microbial biomass carbon (MBC) was determined by soil fumigation-extraction method (Vance et al., 1987). $10 \mathrm{~g}$ of soil was fumigated with $20 \mathrm{ml}$ of $\mathrm{CHCL}_{3}$ in vacuum desiccators for 24 hours in dark and another $10 \mathrm{~g}$ of the same soil sample was refrigerated, then both samples (fumigated and non-fumigated) were extracted with 0.5 $\mathrm{M} \mathrm{K} \mathrm{K}_{2} \mathrm{SO}_{4}$ for half an hour and then the extract was treated with $\mathrm{H}_{2} \mathrm{SO}_{4}$ and orthophosphoric acid, and heated on hot plate at $120{ }^{\circ} \mathrm{C}$ for 30 minutes. After diluting to $250 \mathrm{ml}$ with distilled water, 2-3 drops of ferroin indicator was added and titrated against 0.05 N FAS (Ferrous Ammonium Sulphate) and MBC was calculated:

$$
M B C(\mu g / g \text { soil })=\frac{O C_{F}-O C_{U F}}{K}
$$

where,

- $\mathrm{OC}_{\mathrm{F}}=$ Total amount of EC (Extractable $\left.\mathrm{C}\right)$ in fumigated soil.

- $\mathrm{OC}_{\mathrm{UF}}=$ Total amount of EC (Extractable $\left.\mathrm{C}\right)$ in non-fumigated soil.

- $\mathrm{K}=$ The proportion of microbial $\mathrm{C}$ evolved as $\mathrm{CO}_{2}=0.45$ for 10 days of incubation at $25^{\circ} \mathrm{C}$ (Jenkinson and Ladd, 1981).

\section{Microbial counts}

Total bacterial, fungal and actinomycetes counts were estimated using serial dilution plate technique. One gram of soil was transferred into $10 \mathrm{ml}$ of sterilized water in 250 $\mathrm{ml}$ flask. Sample was mixed by vigorous shaking and now the sample was diluted tenfold $\left(10^{-1}\right.$ dilution). From this, $1 \mathrm{ml}$ of soil suspension was transferred to another $9 \mathrm{ml}$ water blank with the help of sterile pipette and hence sample was diluted to $10^{-2}$. Similarly, dilutions were made up to $10^{-7}$. Different dilutions were made to estimate the different microbial parameters (Table 3).

Table 3. Dilution used for different microbes in the appropriate nutrient media

\begin{tabular}{c|c|c}
\hline Sr. No. & Microbe & Dilution factor \\
\hline 1. & Bacteria & $10^{-6}-10^{-7}$ \\
\hline 2. & Fungi & $10^{-3}-10^{-4}$ \\
\hline 3. & Actinomycetes & $10^{-4}-10^{-5}$ \\
\hline
\end{tabular}

Now, $1 \mathrm{ml}$ of different diluted samples i.e. $10^{-6}-10^{-7}$ were transferred in appropriate pre-sterilized labeled Petri-plates in front of laminar flow. Then $25-30 \mathrm{ml}$ of appropriate media was poured into each dilution plate and shaken to ensure uniform dispersal of the 
cells/suspension in the media. These plates were allowed to solidify on working table of the laminar. Further, the plates are incubated in an inverted position (upside down) for 2-5 days at $28 \pm 2{ }^{\circ} \mathrm{C}$ temperature in an incubator and number of colonies on different dilution media plates were recorded and populations per gram soil were enumerated.

\section{Statistical analysis}

The significance of treatment effects was analyzed using two factorial RBD analysis with OP Stat, CCS HAU Hisar software (Sheoran et al., 1998). Spatial variability graphs were prepared by using ArcGIS software.

\section{Results and Discussion}

\section{Dehydrogenase and phosphatase activity}

Data on dehydrogenase activity in soils under the two farming systems given in Table 4 revealed that organic farming led to significant improvement in dehydrogenase activity over conventional practice. The dehydrogenase activity under organic farming was observed significantly higher than in conventional practice at all the locations with different soil textures. The soil dehydrogenase activity in different locations varied between 18.5 to $46.0 \mu \mathrm{g}$ TPF $\mathrm{g}^{-1}$ soil $24 \mathrm{hr}^{-1}$ in conventional farming while it ranged from 23.8 to $78.6 \mu \mathrm{g}$ TPF $\mathrm{g}^{-1}$ soil $24 \mathrm{hr}^{-1}$ under organic farming. The extent of increase in dehydrogenase activity under organic farming was, however, found to increase with fineness of the texture at different locations. For example, the increase in dehydrogenase activities were $28.6 \%$ in sand $\left(\mathrm{L}_{1}\right), 55.1 \%$ in loamy sand $\left(\mathrm{L}_{8}\right), 68.1 \%$ in sandy loam $\left(\mathrm{L}_{12}\right)$, and $76.6 \%$ in clay loam soil at location $\mathrm{L}_{24}$. The overall dehydrogenase activity which was $35.3 \mu \mathrm{g}$ TPF g ${ }^{-1}$ soil $24 \mathrm{hr}^{-1}$ under conventional farming at different locations was found to increase to $56.1 \mu \mathrm{g}$ TPF g ${ }^{-1}$ soil $24 \mathrm{hr}^{-1}$ under organic farming i.e. an increase of $57.5 \%$. The interactive effect of location and farming system on dehydrogenase activity was also found significant. The significant increase in the dehydrogenase activity in texturally different soils of different locations under conventional and organic farming is presented in Figure 2.

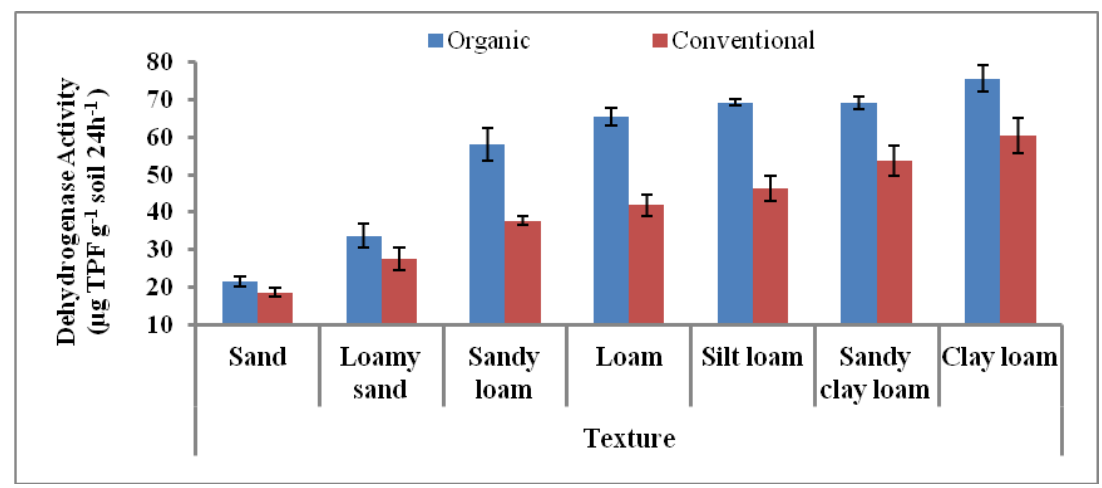

Figure 2. Dehydrogenase activity in different textured soils under conventional and organic farming

Moreover, adoption of organic farming showed a significant increase of alkaline phosphatase in different textured soils over the conventional farming. In general, both 
the farming systems were found to enhance the phosphatase activity with increase in clay content of soil but the extent of increase of alkaline phosphatase was greater under organic farming system than in conventional practice. The values of phosphatase activity varies from 132.6 to $453.1 \mu \mathrm{g}$ PNP g${ }^{-1}$ soil $\mathrm{hr}^{-1}$ among different locations under conventional system of farming while it ranged from 151.8 to $642.8 \mu \mathrm{g} \mathrm{PNP} \mathrm{g}^{-1}$ soil hr $^{-1}$ under organic system of farming. The conversion of conventional system of farming to organic farming resulted in a significant increase in phosphatase activity from 275.8 to 364.1 $\mu \mathrm{g}$ PNP $\mathrm{g}^{-1}$ soil $\mathrm{hr}^{-1}$. The per cent increase in the phosphatase activity under organic farming over conventional in different textured soils showed an increase of 22.8 $\%$ in sand which further increased to $36.8 \%$ in clay loam soil. The phosphatase activity in different textured soils of different locations under conventional and organic farming is represented in Figure 3.

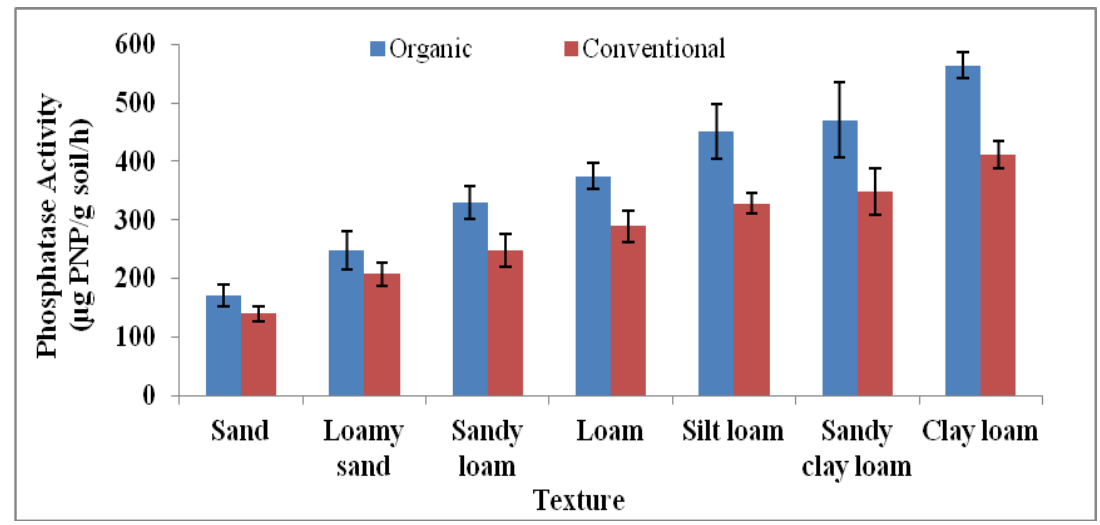

Figure 3. Phosphatase activity in different textured soils under conventional and organic farming

The study confirmed the positive influence and higher microbial activity indices of organic farming (higher enzymatic activity, higher soil microbial biomass carbon content) compared to conventional farming system and the higher enzyme activities under organic practices might be attributed to enhanced nutrient availability from added organics, increase in release of root exudates due to improved crop growth and favorable environment for microbial growth (Burns et al., 2013; Tamilselvi et al., 2015).

Farmyard manure and crop residues provide a source of organic matter, and when returned to soil they increase organic $C$ in soil (Banger et al., 2010) and further, the prevalence of organic substrates stimulated soil microorganisms to produce enzymes responsible for the conversion of unavailable nutrients to plant available forms. Most importantly, a closer look at the relationship between physicochemical and biological indicators of soil health evidenced the significance of organic matter to enzyme activities suggesting enhanced nutrient cycling in systems receiving organic amendments (Sihi et al., 2017). Moreover, phosphatase activity in the soils occurs either in response to plant roots exudates or from microbes such as bacteria or fungi (Dinkelaker and Marschner, 1992) and changes in phosphatase activity can indicate changes in the soil phosphoryl substrates (Rao and Tarafdar, 1992). 
Table 4. Dehydrogenase, phosphatase activities and soil microbial biomass carbon under conventional and organic farming at different locations

\begin{tabular}{|c|c|c|c|c|c|c|c|c|c|}
\hline \multirow{2}{*}{$\begin{array}{l}\text { Location } \\
\quad(\mathrm{L})\end{array}$} & \multicolumn{3}{|c|}{ Dehydrogenase $\left(\mu \mathrm{g}\right.$ TPF $\mathrm{g}^{-1}$ soil $\left.24 \mathrm{hr}^{-1}\right)$} & \multicolumn{3}{|c|}{ Alkaline phosphatase $\left(\mu \mathrm{g}\right.$ PNP g $\mathrm{g}^{-1}$ soil $\left.\mathrm{hr}^{-1}\right)$} & \multicolumn{3}{|c|}{ Microbial biomass carbon $\left(\mathrm{mg} \mathrm{kg}^{-1}\right)$} \\
\hline & Conventional & Organic & Mean & Conventional & Organic & Mean & Conventional & Organic & Mean \\
\hline $\mathbf{L}_{1}$ & 18.5 & 23.8 & 21.1 & 146.4 & 191.5 & 168.9 & 132 & 152 & 142 \\
\hline $\mathbf{L}_{2}$ & 28.7 & 24.2 & 26.5 & 132.6 & 151.8 & 142.2 & 87 & 105 & 96 \\
\hline $\mathbf{L}_{3}$ & 29.6 & 36.7 & 33.1 & 196.2 & 211.7 & 204.0 & 99 & 166 & 132 \\
\hline $\mathbf{L}_{4}$ & 22.6 & 37.9 & 30.2 & 195.2 & 286.4 & 240.8 & 137 & 173 & 155 \\
\hline $\mathbf{L}_{5}$ & 27.4 & 43.6 & 35.5 & 236.7 & 242.6 & 239.6 & 122 & 199 & 160 \\
\hline $\mathbf{L}_{6}$ & 25.4 & 38.0 & 31.7 & 226.7 & 230.8 & 228.7 & 114 & 173 & 143 \\
\hline $\mathbf{L}_{7}$ & 28.7 & 41.5 & 35.1 & 203.3 & 244.2 & 223.7 & 101 & 198 & 149 \\
\hline $\mathbf{L}_{8}$ & 23.3 & 36.1 & 29.7 & 165.6 & 219.7 & 192.6 & 129 & 167 & 148 \\
\hline $\mathrm{L}_{9}$ & 36.1 & 52.8 & 44.4 & 249.1 & 321.3 & 285.2 & 111 & 211 & 161 \\
\hline $\mathbf{L}_{10}$ & 38.1 & 56.7 & 47.4 & 274.8 & 334.6 & 304.7 & 109 & 209 & 159 \\
\hline $\mathbf{L}_{11}$ & 28.4 & 59.4 & 43.9 & 209.4 & 292.8 & 251.1 & 146 & 258 & 202 \\
\hline $\mathbf{L}_{12}$ & 37.6 & 63.2 & 50.4 & 237.6 & 365.4 & 301.5 & 137 & 328 & 232 \\
\hline $\mathbf{L}_{13}$ & 42.3 & 62.7 & 52.5 & 209.2 & 349.2 & 279.2 & 132 & 278 & 205 \\
\hline $\mathbf{L}_{14}$ & 41.8 & 67.8 & 54.8 & 335.1 & 407.4 & 371.2 & 176 & 293 & 234 \\
\hline $\mathbf{L}_{15}$ & 40.3 & 63.9 & 52.1 & 278.6 & 366.8 & 322.7 & 268 & 402 & 335 \\
\hline $\mathbf{L}_{16}$ & 46.3 & 67.9 & 57.1 & 267.3 & 378.2 & 322.5 & 212 & 391 & 301 \\
\hline $\mathbf{L}_{17}$ & 38.8 & 60.3 & 49.5 & 289.4 & 382.7 & 336.0 & 183 & 394 & 288 \\
\hline $\mathbf{L}_{18}$ & 42.4 & 68.7 & 55.9 & 367.2 & 497.6 & 432.4 & 145 & 343 & 244 \\
\hline $\mathbf{L}_{19}$ & 40.5 & 70.3 & 55.4 & 321.1 & 452.8 & 386.9 & 168 & 355 & 261 \\
\hline $\mathbf{L}_{20}$ & 39.5 & 68.7 & 54.1 & 314.1 & 402.7 & 358.4 & 176 & 300 & 238 \\
\hline $\mathbf{L}_{21}$ & 41.7 & 64.3 & 53.0 & 402.2 & 425.2 & 413.7 & 204 & 344 & 274 \\
\hline $\mathbf{L}_{22}$ & 43.2 & 69.2 & 56.2 & 453.1 & 516.4 & 484.6 & 176 & 305 & 240 \\
\hline $\mathbf{L}_{23}$ & 46.0 & 76.4 & 61.2 & 368.2 & 627.4 & 497.3 & 269 & 404 & 336 \\
\hline $\mathbf{L}_{24}$ & 44.5 & 78.6 & 61.5 & 412.3 & 642.8 & 527.5 & 256 & 310 & 283 \\
\hline $\mathbf{L}_{25}$ & 39.8 & 71.9 & 55.8 & 403.7 & 561.8 & 482.5 & 271 & 411 & 341 \\
\hline Mean & 35.3 & 56.1 & & 275.8 & 364.1 & & 162 & 274 & \\
\hline $\begin{array}{l}\text { CD at } \\
5 \%\end{array}$ & \multicolumn{3}{|c|}{$\begin{array}{c}\text { Location }(\mathrm{L})=1.6 \\
\text { Farming system }(\mathrm{F})=4.7, \mathrm{~L} \times \mathrm{F}=7.5\end{array}$} & \multicolumn{3}{|c|}{$\begin{array}{c}\text { Location }(\mathrm{L})=9.9 \\
\text { Farming system }(\mathrm{F})=2.8, \mathrm{~L} \text { x F }=14.1\end{array}$} & \multicolumn{3}{|c|}{$\begin{array}{l}\text { Location }(\mathrm{L})=7.9, \\
\text { Farming system }(\mathrm{F})=2.2, \mathrm{~L} \text { x F }=11.1\end{array}$} \\
\hline
\end{tabular}


These findings agree with several research studies (Mader et al., 2002; Dinesh et al., 2010; Lazcano et al., 2013; Sunita, 2016) where higher microbial biomass and enzyme activities were reported even in a single growing season in response to short-term incorporation of organic manures in organics compared to conventional systems.

This indicates that instant increase in soil enzymatic activities which are associated with a rapid increase in availability of organic substrates required for microbial growth.The dehydrogenase (Figure 4a) and phosphatase (Figure 4b) activities in soils plotted for organic farming against adjoining soils under conventional farming (intercept set at zero) also showed clearly that organic farming is very effective in enhancing dehydrogenase $(\mathrm{y}=0.663 \mathrm{x})$ and phosphatase $(\mathrm{y}=0.738 \mathrm{x})$ over conventional system in Haryana (Figure 4). Moreover, the spatial variability maps for different location are also presented in Figure 5 and Figure 6.

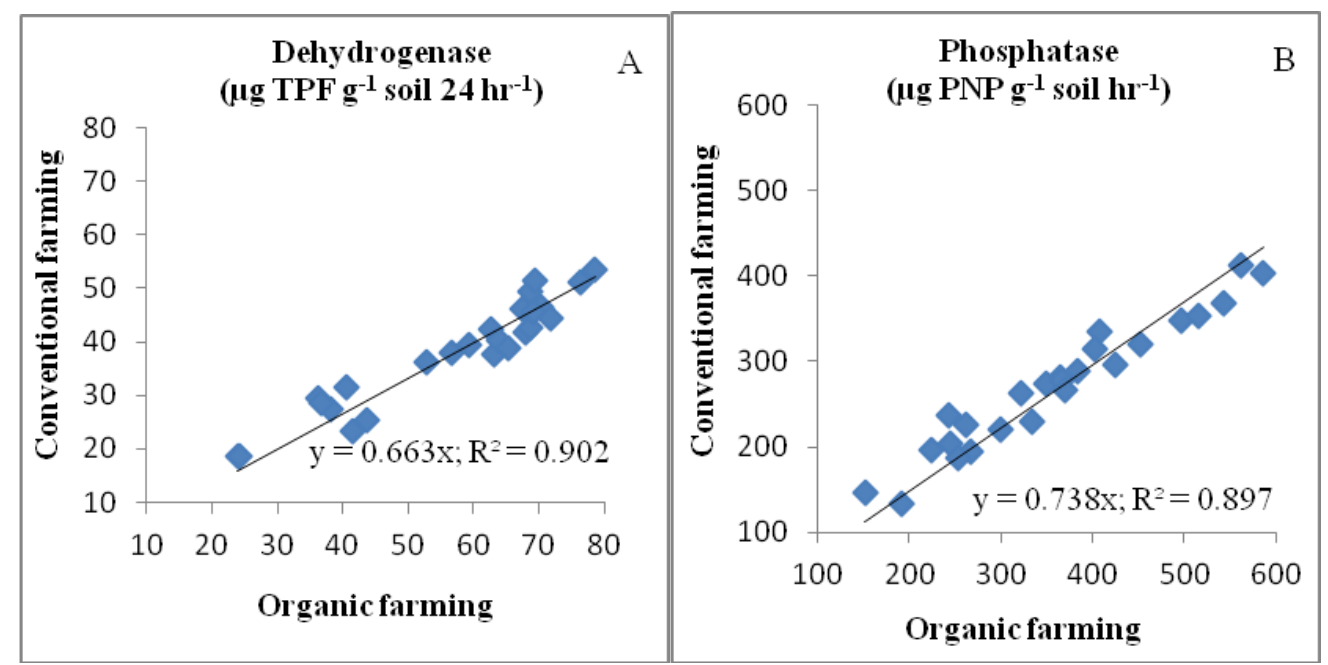

Figure 4. The relationship of dehydrogenase (A) and phosphatase (B) activities in soils under organic and conventional farming systems
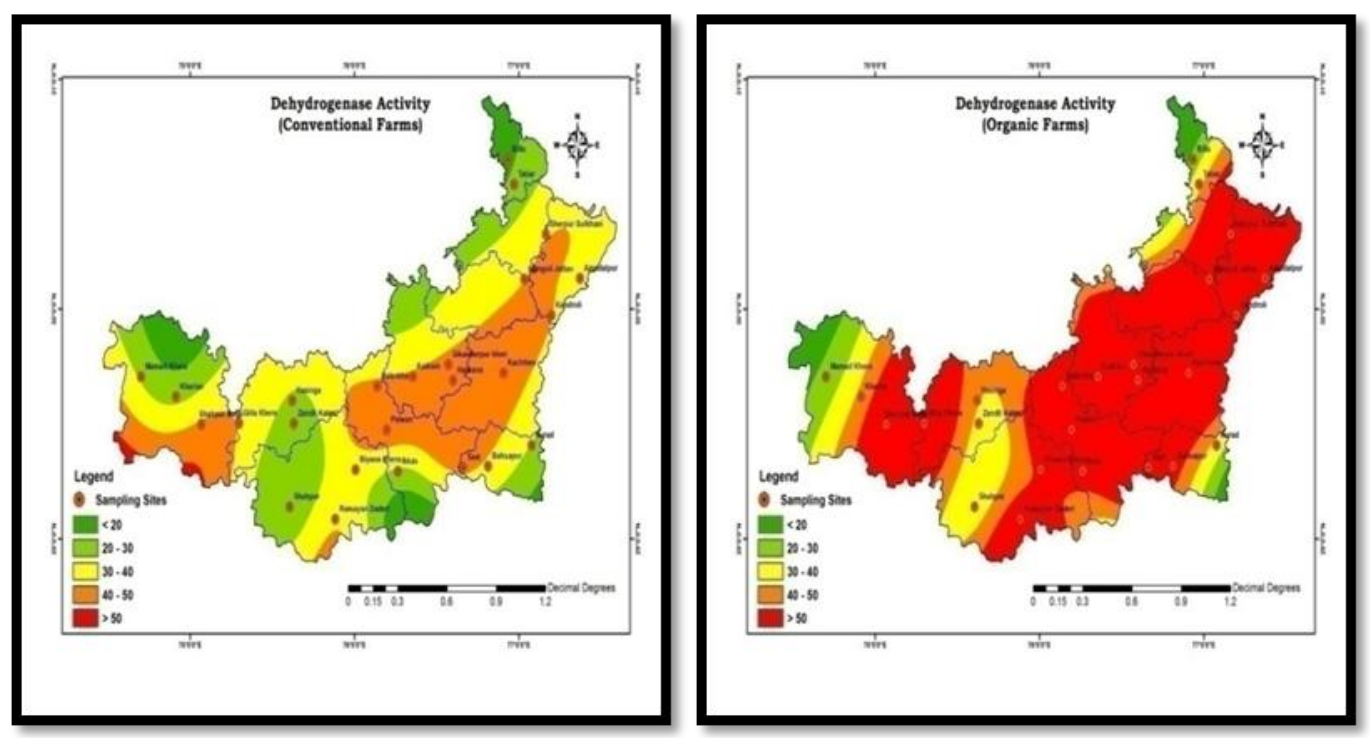

Figure 5. Spatial variability map of dehydrogenase activity in soils under conventional and organic farming systems at different locations of Haryana 

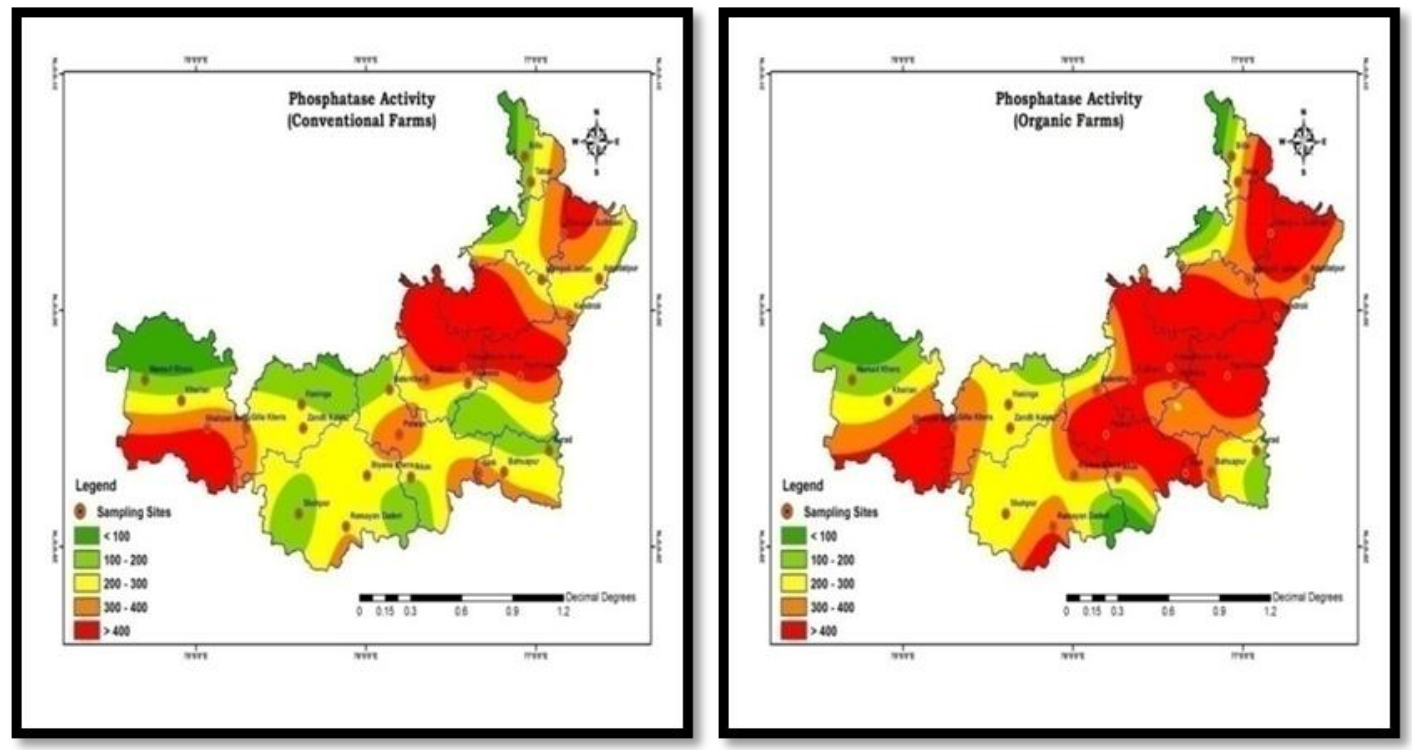

Figure 6. Spatial variability map of phosphatase activity in soils under conventional and organic farming systems at different locations of Haryana

\section{Microbial biomass carbon (MBC)}

The MBC is one of the fractions of SOC which constitutes a very small portion but considered as a good indicator of soil health. Organic farming had significant effect on soil microbial biomass carbon in texturally different soils at different locations (Table 4). Locations with fine textured soils have significantly higher amount of MBC as compared to locations with light textured soils i.e. $\mathrm{L}_{1}$ to $\mathrm{L}_{25}$. Under conventional farming, the $\mathrm{MBC}$ was lowest $\left(87 \mathrm{mg} \mathrm{kg}^{-1}\right)$ in sand at location $\mathrm{L}_{2}$, while it was highest in clay loam soil at location $\mathrm{L}_{25}\left(271 \mathrm{mg} \mathrm{kg}^{-1}\right)$. Similarly, the values of lowest and highest MBC were found to be 105 and $411 \mathrm{mg} \mathrm{kg}^{-1}$ in sand $\left(\mathrm{L}_{2}\right)$ and clay loam soil $\left(\mathrm{L}_{25}\right)$ under organic farming. Overall a significantly higher MBC $(69.1 \%)$ was observed under organically managed $\left(274 \mathrm{mg} \mathrm{kg}^{-1}\right)$ as compared to conventional $\left(162 \mathrm{mg} \mathrm{kg}^{-1}\right)$. The interactive effect of location and farming system was also found significant and the highest MBC content $\left(411 \mathrm{mg} \mathrm{kg}^{-1}\right.$ ) was observed at location $\mathrm{L}_{25}$ under organic farming. Variations in $\mathrm{MBC}$ in different textured soils under conventional and organic farming have also been presented in Figure 7. MBC serves as an important reservoir of plant nutrients (Marumoto et al., 1982; Okur et al., 2009) and soil microbial C decrease with decrease in fineness of soil texture due to declining $\mathrm{C}$ input but observed to be higher in organically managed soils than in conventionally managed due to the permanent input of organic residues with high $\mathrm{C} / \mathrm{N}$ ratio (Schjonning et al., 2002; Crecchioa et al., 2004; Melero et al., 2006; Araujo et al., 2009; Amaral et al., 2011). Furthermore, higher soil microbial biomass carbon in organic farming is mainly due to the regular application of farmyard manure and large carbon inputs in the form of organic amendment. Additionally, farmyard manure supplies readily available $\mathrm{N}$, resulting higher plant biomass. Consequently, more crop residues are incorporated in soil and thereby higher organic matter levels are maintained (Roldan et al., 2005). This also provides a favorable environment for microorganisms, contributing to a highly diverse and stable microbial community structure in organic farming systems (Wada and Toyota, 2007). 


$$
-3679-
$$

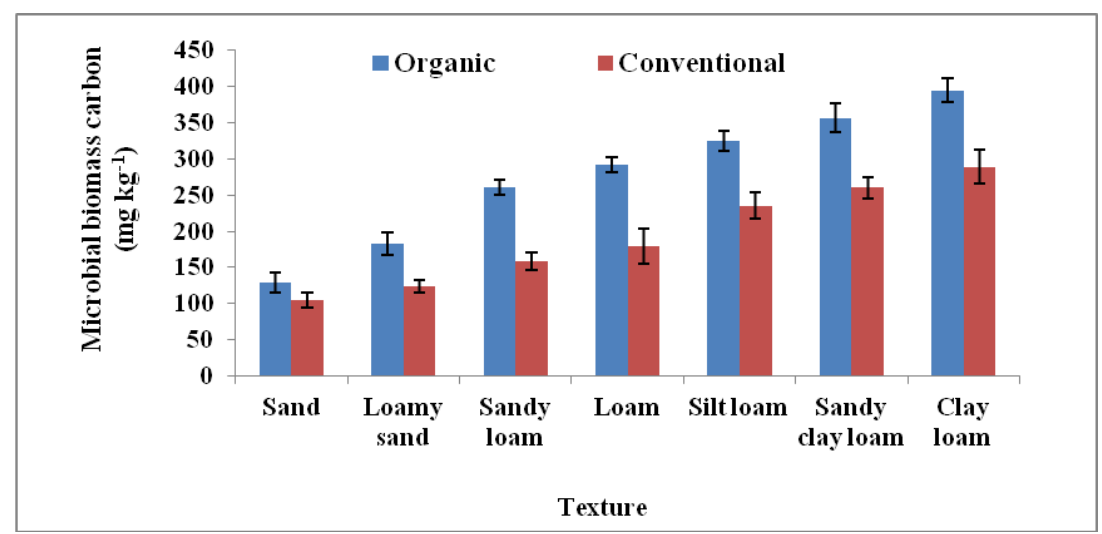

Figure 7. Microbial biomass carbon in different textured soils under conventional and organic farming

The plot of the microbial biomass carbon of soils under organic farming against the microbial biomass carbon of the adjoining soils under conventional farming (intercept set at zero) showed that organic farming in general increases microbial biomass carbon $(\mathrm{y}=0.638 \mathrm{x})$ of soils (Figure 8). The spatial variability maps of MBC for different location are also presented in Figure 9.

\section{Total bacterial, fungal and actinomycetes counts}

Wide variation of soil microbial populations has been recorded at different locations under organic and conventional farming systems as well (Table 5). The consistent increase was noticed in the population of bacteria, fungi and actinomycetes at all the locations under organic farming but the extent of increase was more pronounced in heavy textured soils subjected to organic manures such as FYM, neem cake or vermicompost.

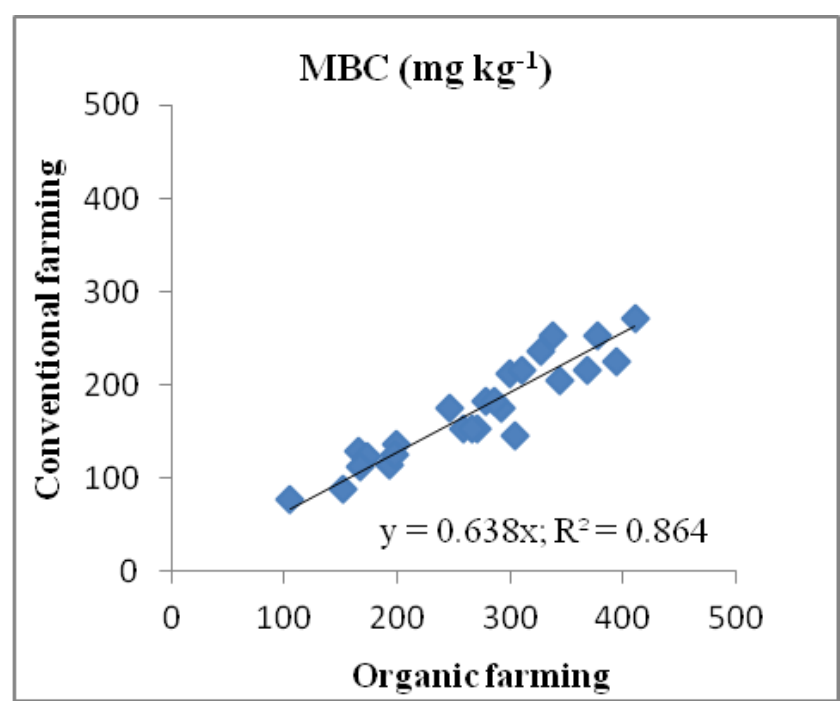

Figure 8. The relationship of microbial biomass carbon activities in soils under organic and conventional farming systems 
Table 5. Effect of organic and conventional farming practices on microbial population in soil at different locations

\begin{tabular}{|c|c|c|c|c|c|c|c|c|c|}
\hline \multirow{2}{*}{$\begin{array}{l}\text { Location } \\
\text { (L) }\end{array}$} & \multicolumn{3}{|c|}{ Bacteria $\left(\mathrm{CFU} \mathrm{g}^{-1}\right.$ soil $\left.\times \mathbf{1 0}^{6}\right)$} & \multicolumn{3}{|c|}{ Fungi $\left(\right.$ CFU g ${ }^{-1}$ soil $\left.\times 10^{3}\right)$} & \multicolumn{3}{|c|}{ Actinomycetes $\left(\mathrm{CFU} \mathrm{g^{-1 }}\right.$ soil $\left.\times 10^{4}\right)$} \\
\hline & Conventional & Organic & Mean & Conventional & Organic & Mean & Conventional & Organic & Mean \\
\hline $\mathbf{L}_{1}$ & 6.00 & 8.75 & 7.38 & 5.81 & 6.23 & 6.02 & 7.89 & 11.55 & 9.72 \\
\hline $\mathbf{L}_{2}$ & 5.75 & 6.75 & 6.25 & 4.54 & 5.69 & 5.12 & 5.84 & 9.62 & 7.73 \\
\hline $\mathbf{L}_{3}$ & 9.89 & 13.11 & 11.50 & 8.01 & 10.62 & 9.32 & 8.11 & 12.59 & 10.35 \\
\hline $\mathbf{L}_{4}$ & 11.61 & 17.84 & 14.73 & 9.40 & 14.45 & 11.93 & 12.08 & 17.94 & 15.01 \\
\hline $\mathbf{L}_{5}$ & 10.96 & 16.77 & 13.87 & 8.88 & 13.58 & 11.23 & 10.18 & 14.23 & 12.20 \\
\hline $\mathbf{L}_{6}$ & 12.42 & 20.16 & 16.29 & 10.06 & 16.33 & 13.19 & 10.35 & 13.28 & 11.82 \\
\hline $\mathbf{L}_{7}$ & 14.19 & 21.92 & 18.06 & 11.50 & 17.75 & 14.63 & 13.63 & 21.56 & 17.59 \\
\hline $\mathbf{L}_{8}$ & 8.81 & 15.94 & 12.38 & 7.14 & 12.91 & 10.03 & 9.31 & 15.61 & 12.46 \\
\hline $\mathrm{L}_{9}$ & 13.33 & 17.84 & 15.59 & 10.80 & 14.45 & 12.63 & 14.32 & 19.84 & 17.08 \\
\hline $\mathbf{L}_{10}$ & 16.72 & 24.37 & 20.54 & 13.54 & 19.74 & 16.64 & 17.02 & 23.12 & 20.07 \\
\hline $\mathbf{L}_{11}$ & 12.26 & 19.99 & 16.13 & 9.93 & 16.20 & 13.06 & 14.16 & 20.87 & 17.52 \\
\hline $\mathbf{L}_{12}$ & 14.53 & 21.10 & 17.82 & 11.76 & 17.10 & 14.43 & 12.85 & 20.32 & 16.59 \\
\hline $\mathbf{L}_{13}$ & 14.86 & 22.04 & 18.45 & 12.04 & 17.85 & 14.94 & 10.35 & 21.17 & 15.76 \\
\hline $\mathbf{L}_{14}$ & 16.12 & 25.70 & 20.91 & 13.06 & 20.81 & 16.94 & 16.44 & 26.57 & 21.50 \\
\hline $\mathbf{L}_{15}$ & 18.49 & 29.03 & 23.76 & 14.98 & 23.51 & 19.24 & 15.35 & 23.29 & 19.32 \\
\hline $\mathbf{L}_{16}$ & 13.61 & 22.58 & 18.10 & 11.03 & 18.28 & 14.66 & 14.66 & 24.32 & 19.49 \\
\hline $\mathbf{L}_{17}$ & 14.90 & 21.07 & 17.98 & 12.07 & 17.07 & 14.57 & 16.96 & 22.62 & 19.79 \\
\hline $\mathbf{L}_{18}$ & 14.26 & 19.35 & 16.80 & 11.55 & 15.68 & 13.61 & 19.49 & 27.43 & 23.46 \\
\hline $\mathbf{L}_{19}$ & 16.81 & 24.51 & 20.66 & 13.62 & 19.85 & 16.74 & 14.83 & 25.53 & 20.18 \\
\hline $\mathbf{L}_{20}$ & 18.49 & 30.74 & 24.62 & 14.98 & 24.90 & 19.94 & 18.78 & 27.77 & 23.28 \\
\hline $\mathbf{L}_{21}$ & 15.48 & 31.39 & 23.44 & 12.54 & 25.42 & 18.98 & 20.46 & 29.64 & 25.05 \\
\hline $\mathbf{L}_{22}$ & 18.49 & 33.81 & 26.15 & 14.98 & 27.39 & 21.19 & 20.87 & 31.39 & 26.13 \\
\hline $\mathbf{L}_{23}$ & 20.37 & 35.47 & 27.92 & 16.50 & 28.74 & 22.62 & 26.15 & 43.99 & 35.07 \\
\hline $\mathbf{L}_{24}$ & 28.16 & 40.42 & 34.29 & 22.81 & 32.74 & 27.78 & 24.53 & 35.66 & 30.09 \\
\hline $\mathbf{L}_{25}$ & 25.16 & 39.13 & 32.15 & 20.38 & 31.69 & 26.04 & 22.60 & 41.06 & 31.83 \\
\hline Mean & 14.87 & 23.19 & & 12.08 & 18.76 & & 15.09 & 23.24 & \\
\hline CD at $5 \%$ & \multicolumn{3}{|c|}{$\begin{array}{l}\text { Location }(\mathrm{L})=1.57 \\
\text { Farming system }(\mathrm{F})=0.44, \mathrm{~L} \times \mathrm{F}=2.22\end{array}$} & \multicolumn{3}{|c|}{$\begin{array}{l}\qquad \begin{array}{l}\text { Location }(\mathrm{L})=1.34, \\
\text { Farming system }(\mathrm{F})=0.38, \mathrm{~L} \times \mathrm{F}=1.90\end{array}\end{array}$} & \multicolumn{3}{|c|}{$\begin{array}{l}\text { Location }(\mathrm{L})=1.91 \\
\text { Farming system }(\mathrm{F})=0.54, \mathrm{~L} \text { x } \mathrm{F}=2.7\end{array}$} \\
\hline
\end{tabular}



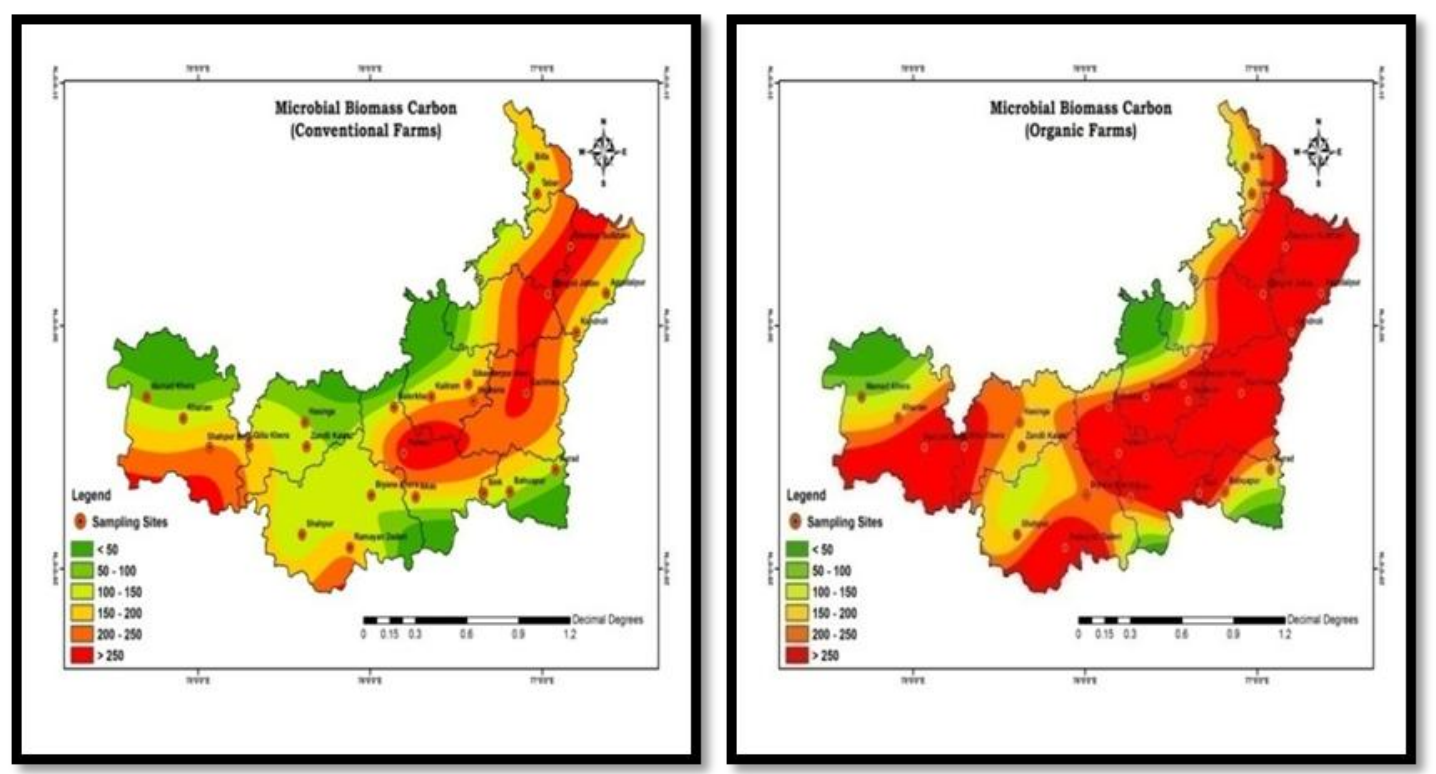

Figure 9. Spatial variability map of $M B C$ in soils under conventional and organic farming systems at different locations of Haryana

The mean value of different locations pertaining to population of bacteria was observed to be $14.87 \times 10^{6} \mathrm{CFU} \mathrm{g}^{-1}$ soil under conventionally managed soils which was significantly increased to $23.34 \times 10^{6} \mathrm{CFU} \mathrm{g}{ }^{-1}$ soil upon conversion to organic farming. Similarly, fungi population was significantly increased from $12.08 \times 10^{3} \mathrm{CFU} \mathrm{\textrm {g } ^ { - 1 }}$ soil to $18.76 \times 10^{3} \mathrm{CFU} \mathrm{\textrm {g } ^ { - 1 }}$ soil and actinomycetes population from $15.09 \times 10^{4} \mathrm{CFU} \mathrm{g}^{-1}$ soil to $22.57 \times 10^{4} \mathrm{CFU} \mathrm{g} \mathrm{g}^{-1}$ soil under organic farming as compared to conventional farming practices. The average populations of bacteria, fungi and actinomycetes in the soils at different locations under organic farming were $56.9 \%$, $55.2 \%$ and $49.5 \%$, respectively, higher than those in the conventionally managed soils. In different textured soils, the bacteria showed variations from $6.25 \times 10^{6}$ in sand to $24.56 \times 10^{6} \mathrm{CFU}$ $\mathrm{g}^{-1}$ soil in clay loam soil whereas fungal and actinomycetes population varied from $5.17 \times 10^{3}$ in sand to $23.58 \times 10^{3}$ in clay loam soil and $6.86 \times 10^{4}$ in sand to $28.89 \times 10^{4} \mathrm{CFU} \mathrm{g}^{-1}$ soil in clay loam, respectively, under conventional farming (Figures 10 to 12).

Addition of various nutrient inputs through various sources such as FYM, neem cake and vermicompost under organic farming practices exhibited huge variation and resulted in rapid stimulation of microbial growth and subsequently, the increase in bacteria, fungi and actinomycetes population was observed to be $7.75 \times 10^{6}, 5.96 \times 10^{3}$ and $8.28 \times 10^{4} \mathrm{CFU} \mathrm{g}^{-1}$ soil in sand to $38.34 \times 10^{6}, 31.06 \times 10^{3}$ and $35.89 \times 10^{4} \mathrm{CFU} \mathrm{g} \mathrm{g}^{-1}$ soil, respectively, in clay loam soil. The significant increase in population of these microorganisms under organic farming, however, observed to be significant only in loamy soils as compared to conventional farming system.

Growth of bacteria, fungi and actinomycetes on different nutrient media has also been shown in Plates 1 to 3. The average populations of bacteria, fungi and actinomycetes in the soils at different locations under organic farming were $56.9 \%, 55.2 \%$ and $49.5 \%$, respectively, higher than those in the conventionally managed soils. 


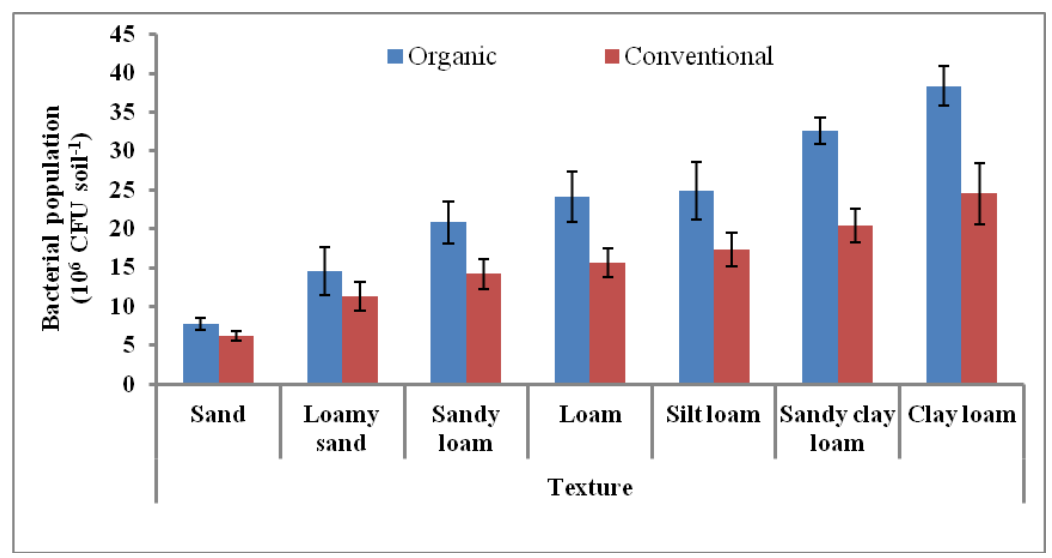

Figure 10. Bacterial populations in different textured soils under conventional and organic farming systems

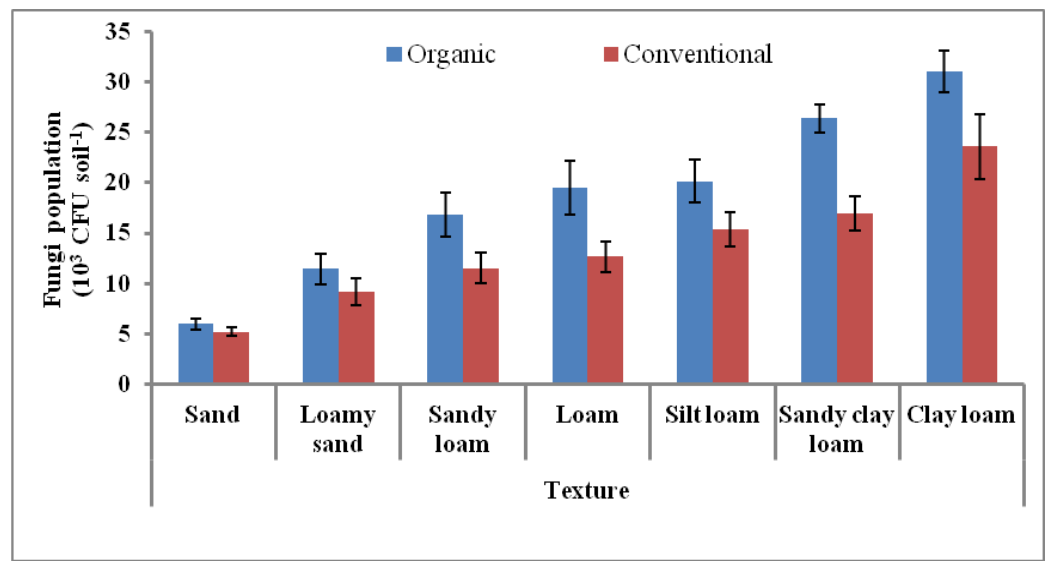

Figure 11. Fungal populations in different textured soils under conventional and organic farming systems

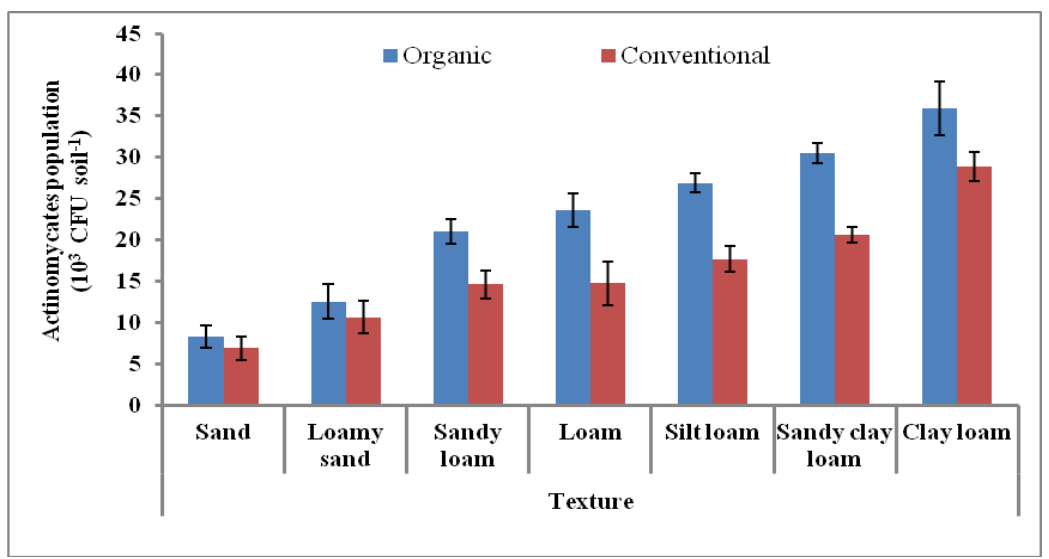

Figure 12. Actinomycetes populations in different textured soils under conventional and organic farming systems 


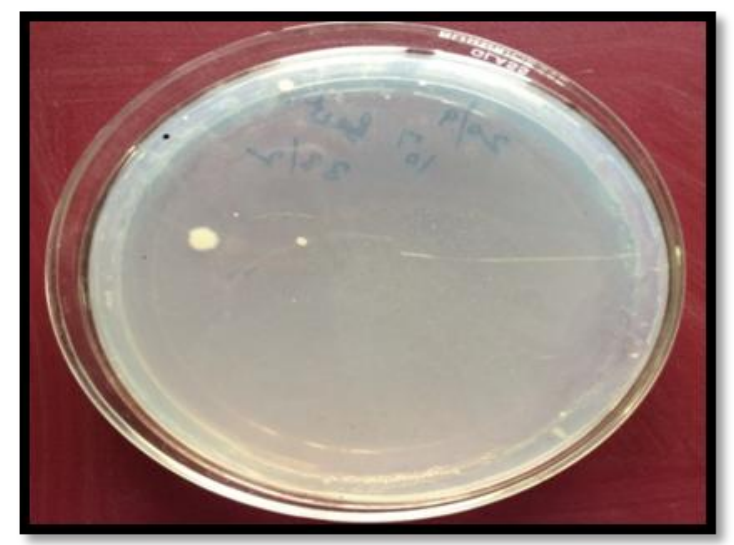

Conventional

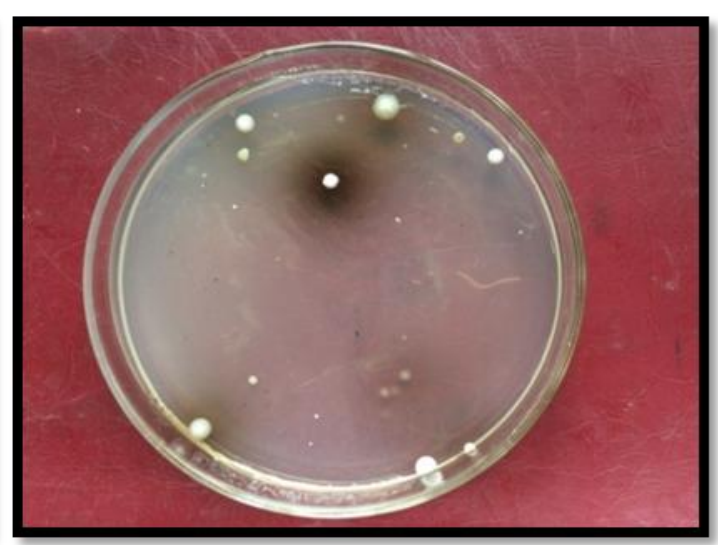

Organic

Plate 1. Growth of different bacterial species on nutrient agar media

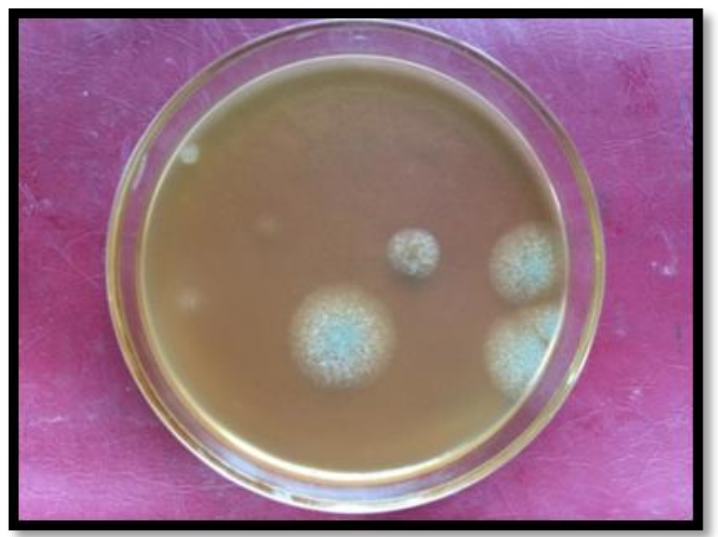

Conventional

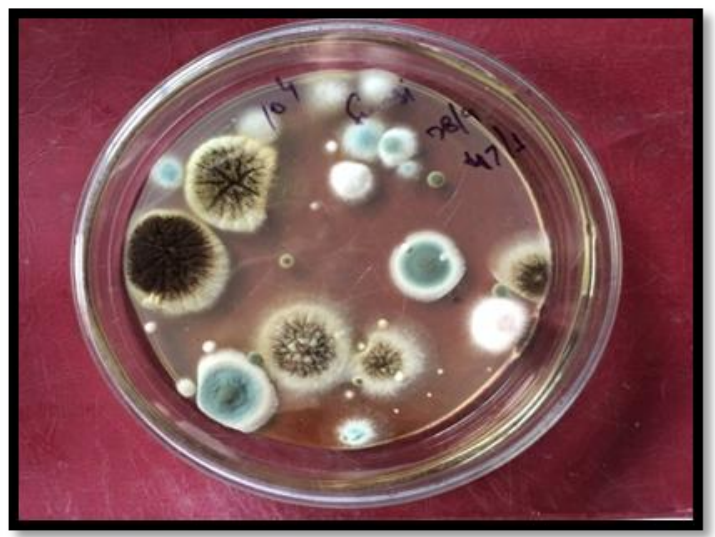

Organic

Plate 2. Growth of different fungal species on potato dextrose media

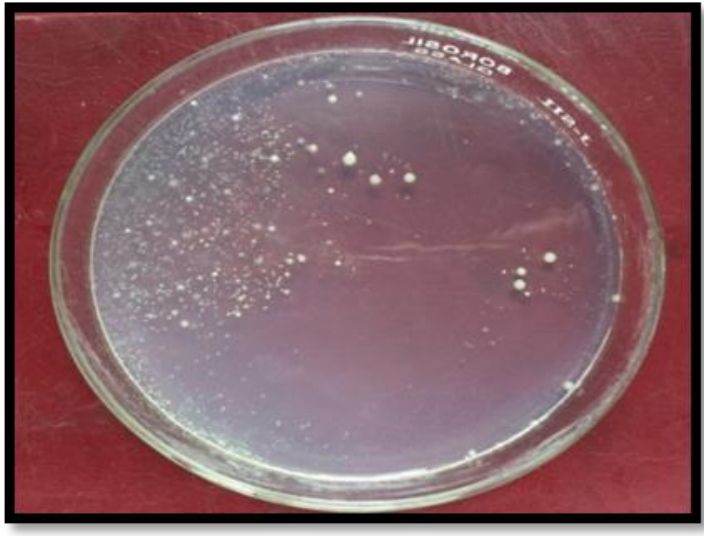

Conventional

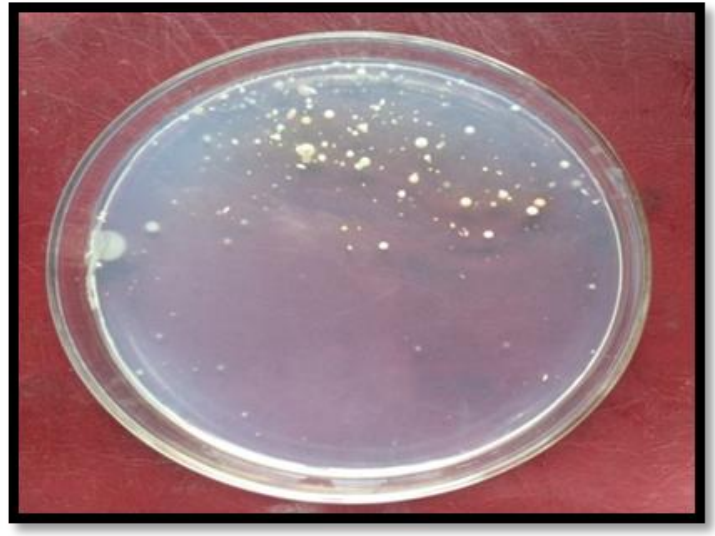

Organic

Plate 3. Growth of different actinomycetes species on kenknight media 
The addition of FYM, neem cake, vermicompost and other organic sources of nutrients enhanced growth of microbial populations which may be attributed to the increment in organic matter in soil that serves as a food and energy source for microbes. These results are supported by the findings of Bobulska et al. (2015). In recent years, multiple studies comparing conventional and organic agriculture have reported differences in soil properties, increased microbial activity and diversity in organically managed soils, or distinct microbial profiles between the two systems (Wu et al., 2008; Moeskops et al., 2010; Bobulska et al., 2015). Results from our study clearly indicated that soil texture significantly affected bacteria, fungi and actinomycetes populations, and higher growth of microbial populations was observed in heavy textured soils (clay loam) than light textured soils (sand). Among six textural classes, the highest growth of microbial populations was observed in clay loam and the lowest in sand and there was positive a correlation between soil organic carbon and growth of microbial populations. Several researches documented that fine soils were found to be more suitable for bacteria, fungi and actinomycetes survival because smaller size particles provide a protective habitat for microorganisms through pore size exclusion of predators (Sessitsch et al., 2001 and Zhang et al., 2007). Alternatively, higher microbial population in clay loam soils may be due to a higher organic matter content, water retention characteristics and nutrient availability (Grayston et al., 2004). Microbial activity in soil is strongly influenced by the clays and humates which bind organic chemicals, inorganic ions, and water films to their surfaces (Van et al., 1996).

The bacterial (Figure 13a), fungal (Figure 13b) and actinomycetes (Figure 13c) populations of soils plotted for organic farming against adjoining soils under conventional farming (intercept set at zero) also showed clearly that organic farming had a promising effect in increasing bacterial $(\mathrm{y}=0.632 \mathrm{x})$, fungal $(\mathrm{y}=0.633 \mathrm{x})$ and actinomycetes populations $(\mathrm{y}=0.642 \mathrm{x})$ over conventional system in Haryana (Figure 13). The spatial variability maps of bacteria, fungi and actinomycetes at different locations are also presented in Figures 14 to 16.

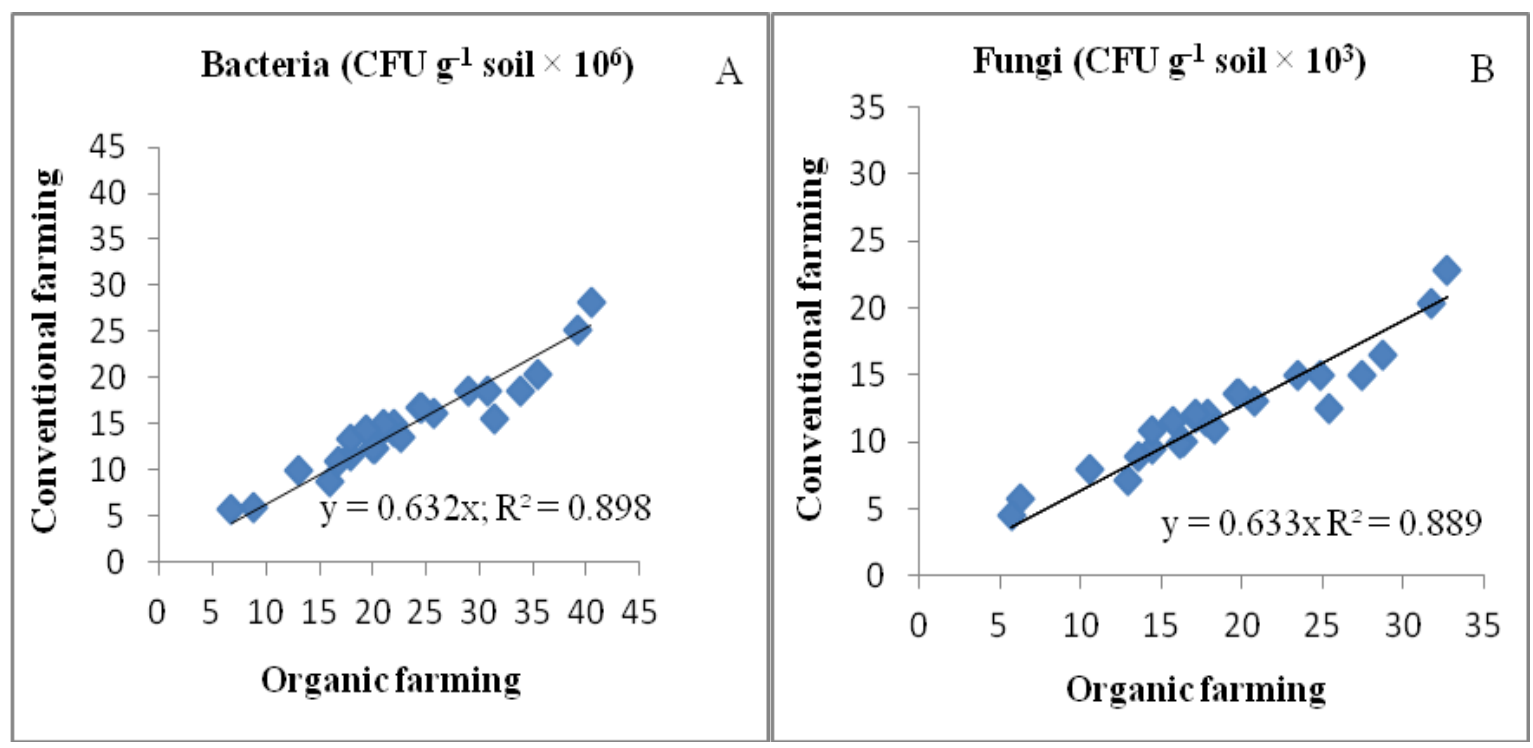




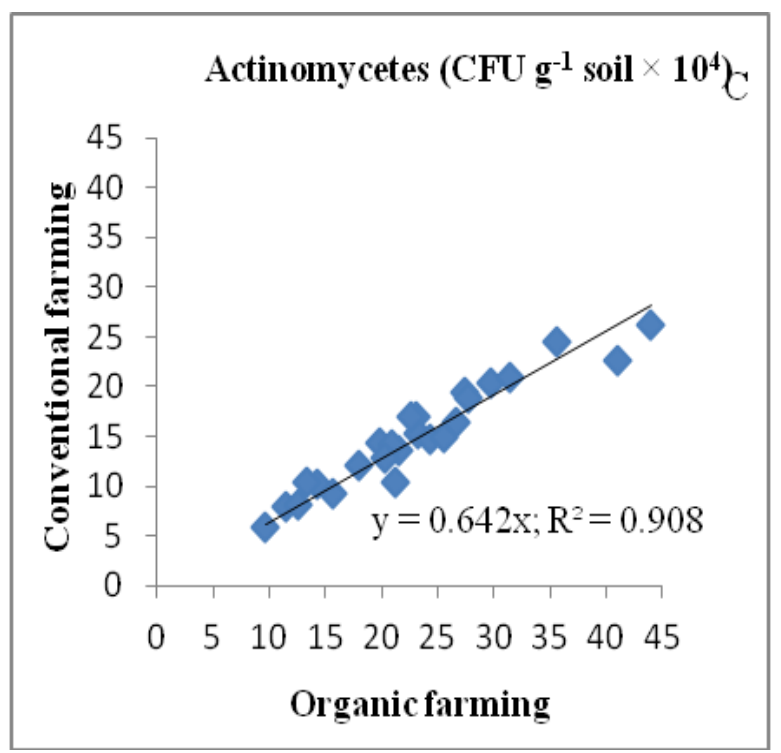

Figure 13. The relationship of bacteria, fungi and actinomycetes populations in soils under organic and conventional farming system

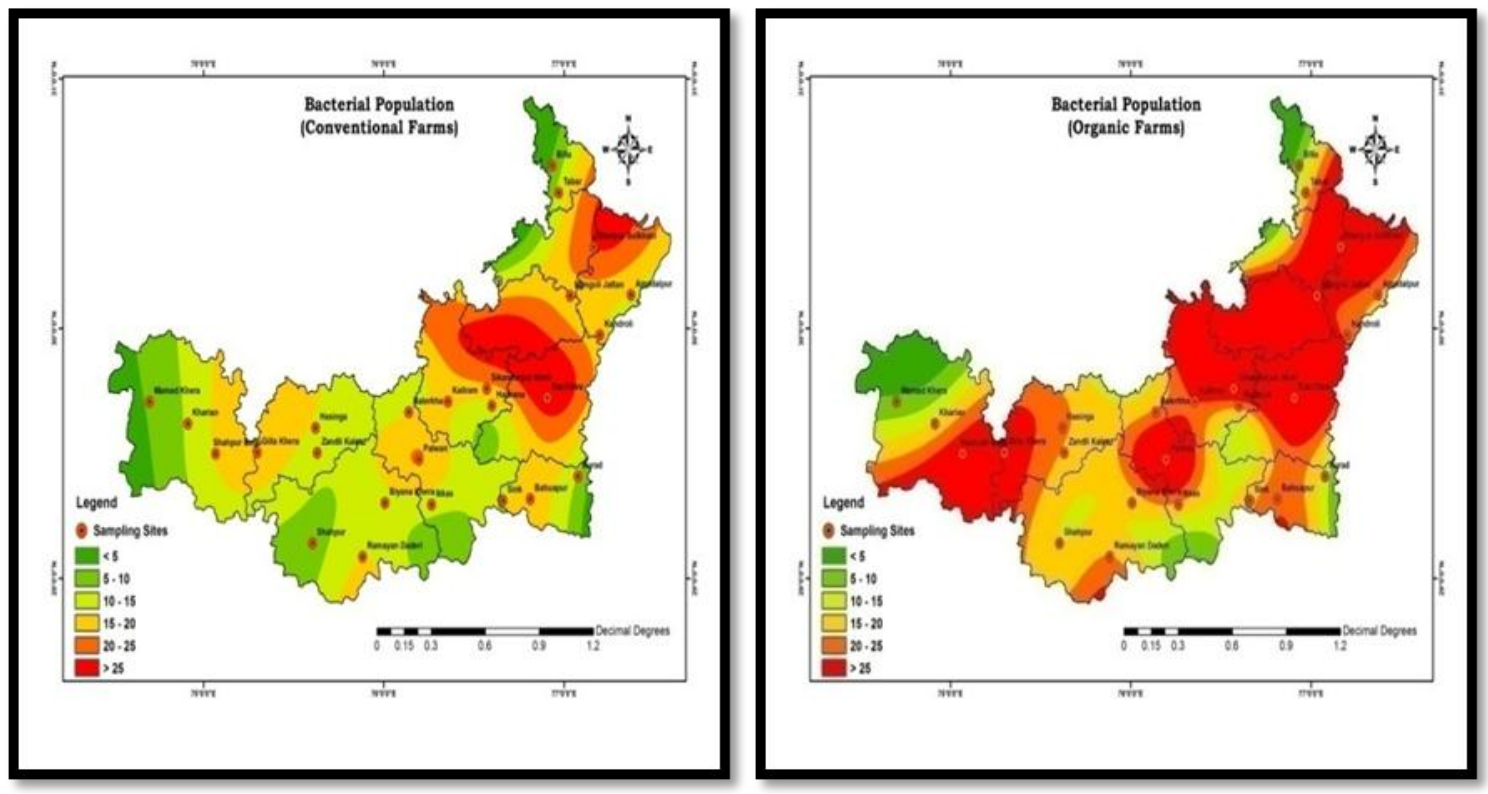

Figure 14. Spatial variability map of bacterial populations in soils under conventional and organic farming systems at different locations of Haryana 

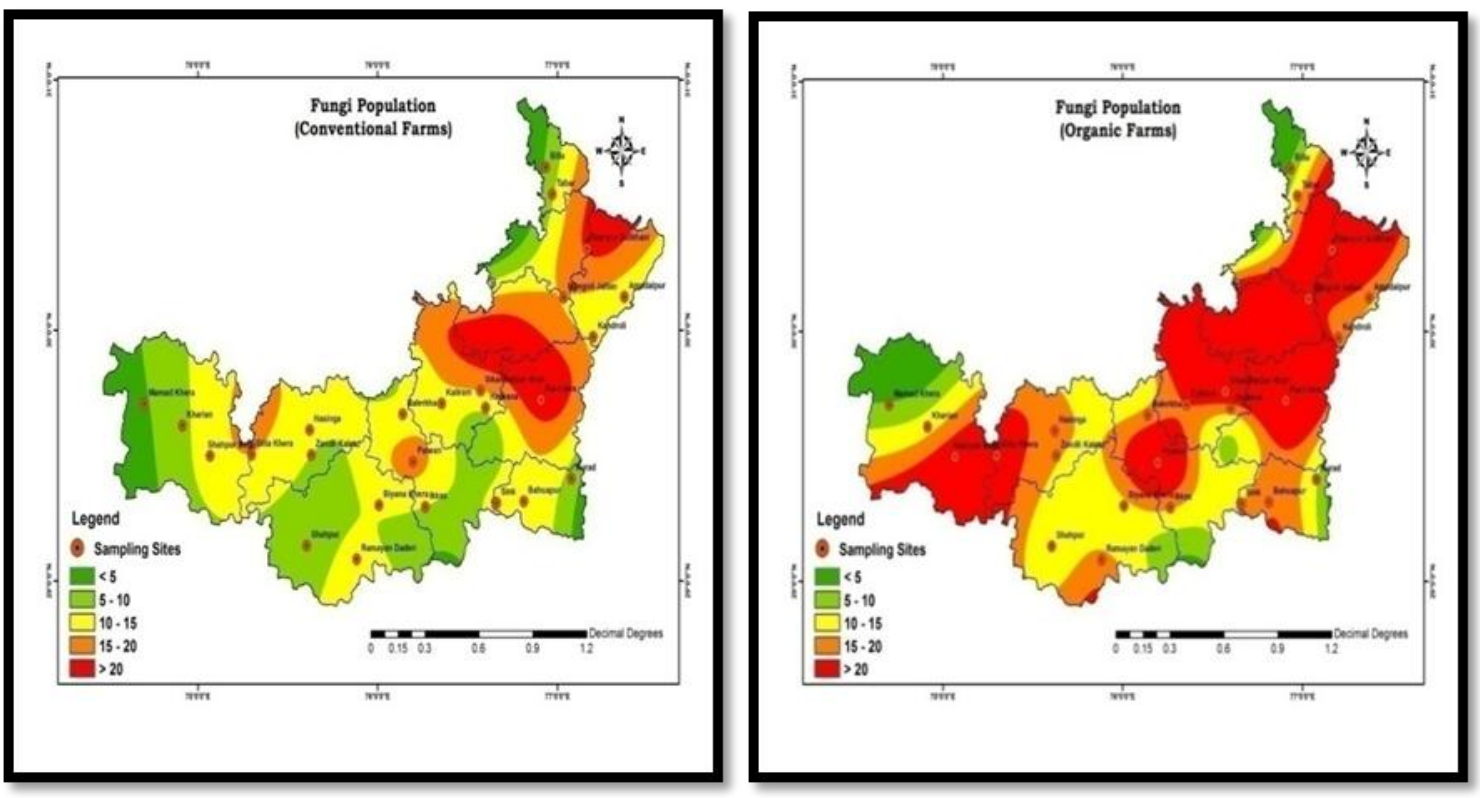

Figure 15. Spatial variability map of fungal populations in soils under conventional and organic farming systems at different locations of Haryana
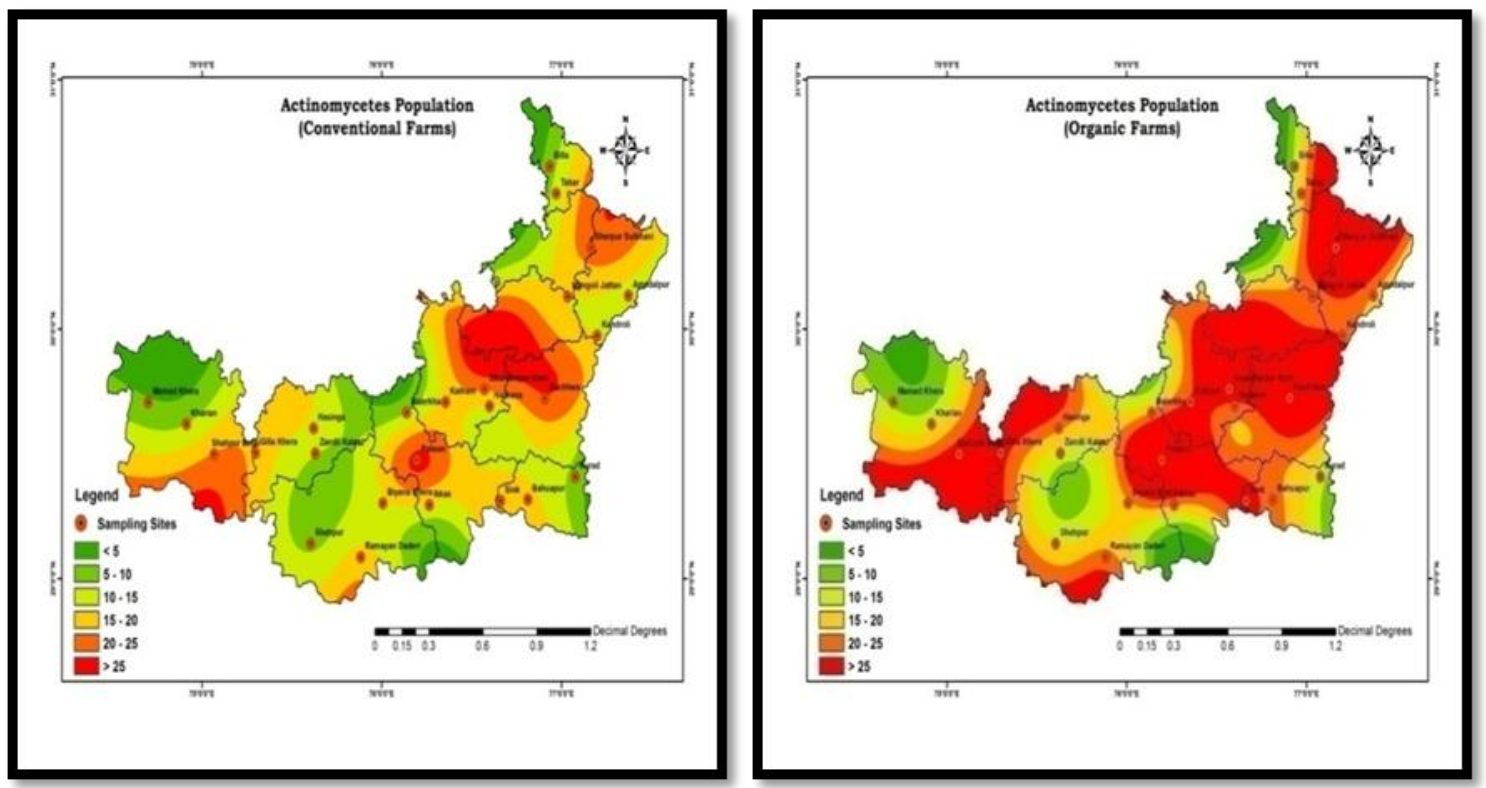

Figure 16. Spatial variability map of actinomycetes populations in soils under conventional and organic farming systems at different locations of Haryana 


\section{Conclusion}

The biological properties of soils in terms of enzymatic activities, microbial biomass carbon and total CFU of bacterial, fungal and actinomycetes populations were studied for the organic and conventional farming practices and they were found to be superior in the case of organic farming practices as compared to their counterparts. Higher organic matter input through application of various organic manures under organic farming practices is the key factor in enhancing the enzymatic activities and soil microbial biomass carbon along with higher growth of microbial populations in soil. The results from the study indicate that the management practices have clear positive and significant effects on various biological properties of soils. Enzymatic and microbial responses to chemical fertilizers and pesticides under conventional farming indicated the resource limitation and substrate availability to these biological communities in soil. Thus, microbiological properties of soil can serve as potential heath indicator of soils as being affected by different management practices.

\section{REFERENCES}

[1] Amaral, H. F., Ozinaldo, J., Sena, A., Regina, K., Schwan, E. F., Balota, E. L., Andrade, D. S. (2011): Soil chemical and microbial properties in vineyards under organic and conventional management in southern Brazil. - R. Bras. Ci. Solo 35: 1517-1526.

[2] Amir, K., Fouzia, I. (2011): Chemical nutrient analysis of different composts (Vermicompost and Pitcompost) and their effect on the growth of a vegetative crop Pisumsativum. - Asian J. of Plant Sci. and Res. 1(1): 116-130.

[3] Anonymous (2016): APEDA, Ministry of Commerce and Industry, Government of India.

[4] Araujo, A. S. F. (2009): Soil microbial activity in conventional and organic agricultural systems. - Sustainability 1: 268-276.

[5] Baum, C., Leinweber, P., Schlichting, A. (2003): Effect of chemical condition in re-wetted peats: temporal variation in microbial biomass and acid phosphatase activity within the growing season. - Applied Soil Ecology 22: 1-12.

[6] Bobulska, L., Fazekasova, D., Angelovicova, L., Kotorova, D. (2015): Impact of ecological and conventional farming systems on chemical and biological soil quality indices in a cold mountain climate in Slovakia. - Biological Agriculture and Horticulture 26: 2-17.

[7] Burns, R. G., De Forest, J. L., Marxsen, J., Sinsabaugh, R. L., Stromberger, M. E., Wallemstein, M. D. (2013): Soil enzymes in a changing environment: Current knowledge and future directions. - Soil Biology \& Biochemistry 32: 1547-1559.

[8] Casida, L. E., Klein D. A., Santoro, Thomas (1964): Soil dehydrogenase activity. - Soil Science 98(6): 371-376.

[9] Crecchioa, C., Gelsominob, A., Ambrosolic, R., Minatic, J. L., Ruggiero, R. (2004): Functional and molecular responses of soil microbial communities under differing soil management practices. - Soil Biology \& Biochemistry 36: 1873-1883.

[10] Dinesh, R., Srinivasan, V., Hamza, S., Manjusha, A. (2010): Short term incorporation of organic manures and biofertilizers influences biochemical and microbial characteristics of soils under an annual crop [Turmeric (Curcuma longa L.)]. - Bioresource Technology 101: 4697-4702.

[11] Dinkelaker, B., Marschner, H. (1992): In vivo demonstration of acid phosphatase activity in the rhizosphere of soil grown plants. - Plant and Soil 144: 199-205. 
Sheoran et al.: Long term effect of farming practices on microbial biomass carbon, enzyme activities and microbial populations in different textured soils -3688 -

[12] Edwards, C. A., Lofty, J. R. (1974): The invertebrate fauna of the Park Grassplots I: Soil fauna. - Rothamsted Report, part 2: 133-154.

[13] Grayston, S., Campbell, C., Bardgett, R., Mawdsley, J., Clegg, C., Ritz, K. (2004): Assessing shifts in microbial community structure across a range of grasslands of differing management intensity using CLPP, PLFA and community DNA techniques. - Applied Soil Ecology 25(1): 63-84.

[14] Jenkinson, D. S., Ladd, J. N. (1981): Microbial biomass . in soil: measurement and turnover. - Soil Biochem. 5: 415-471.

[15] Jolankai, P. Z., Toth, Kismanyoky (2006): Effect of nitrogen and pesticides on the yield and protein content of winter wheat. - Cereal Research Commounication 34: 509-512.

[16] Kotcon, J. B. (2011): Population Dynamics of Earthworms in Organic Farming Systems. In: Karaca A. (eds) Biology of Earthworms. - Soil Biol., 24: Springer, Berlin, Heidelberg.

[17] Lazcano, C., Go, B., Revilla, M. P., Domnguez, J. (2013): Short-term effects of organic and inorganic fertilizers on soil microbial community structure and function. - Biology and Fertility of Soils 49: 723-733.

[18] Mader, P., Fließbach, A., Dubois, D., Gunst, L., Fried, P., Niggli, U. (2002): Soil fertility and biodiversity in organic farming. - Science 296: 1694-1697.

[19] Maharjan, M., Sanaullah, M., Bahar, S., Razavi, Kuzyakov, Y. (2017): Effect of land use and management practices on microbial biomass and enzyme activities in subtropical top-and sub-soils. - Applied Soil Ecology 113: 22-28.

[20] Marumoto, T., Anderson, J. P. E., Domsch, K. H. (1982): Mineralization of nutrients from soil microbial biomass. - Soil Biology \& Biochemistry 14: 469-475.

[21] Melero, S. (2006): Chemical and biochemical properties in a silty loam soil under conventional and organic management. - Soil and Tillage Research 90: 162-170.

[22] Moeskops, M.B., Sukristiyonubowo, B., Buchana, D., Sleutel, S., Herawaty, L., Husenb, E., Saraswati, R., Setyorini, D., De, N. S. (2010): Soil microbial communities and activities under intensive organic and conventional vegetable farming in West Java, Indonesia. Applied Soil Ecology 45: 112-120.

[23] Okur, N., Ahmed, A., Muzaffer, C., Selçuk, G. N., Huseyin, H. K. (2009): Microbial biomass and enzyme activity in vineyard soils under organic and conventional farming systems. Turkish Journal of Agriculture and Forestry 33: 413-423.

[24] Pimentel, D., Edwards, C. A. (1982): Pesticide and Ecosystem. - Bioscience 32: 595-600.

[25] Poudel, D. D., Horwath, W. R., Lanini, W. T., Temple, S. R., Bruggen, A. H. C. (2002): Comparison of soil $\mathrm{N}$ availability and leaching potential, crop yields and weeds in organic, low-input and conventional farming systems in northern California. - Agriculture, Ecosystems \& Environment 90: 125-137.

[26] Rai, N., Ashiya, P., Rathore, D. S. (2014): Comparative Study of the Effect of Chemical Fertilizers and Organic Fertilizers on Eisenia foetida. - Int. J. Innov. Res. Sci. Eng. Technol. 3(5): 12991-12998.

[27] Rao, A. V., Tarafdar, J. C. (1992): Seasonal changes in available phosphorus and different enzyme activities in arid soils. - Annals of Arid Zone 31: 185-189.

[28] Roldan, A., Salinas-Garcia, J. R., Alguacil, M. M., Diaz, E., Caravaca, F. (2005): Soil enzyme activities suggest advantages of conservation tillage practices in sorghum cultivation under subtropical conditions. - Geoderma 129: 178-185.

[29] Schjonning, P., Elmholt, S., Munkholm, L. J., Debosz, K. (2002): Soil quality aspects of humid sandy loams as influenced by organic and conventional long-term management. Agriculture, Ecosystems \& Environment 88: 195-214. 
[30] Sessitsch, A., Weilharter, A., Gerzabek, M. H., Kirchmann, H., Kandeler, E. (2001): Microbial population structures in soil particle size fractions of a long-term fertilizer field experiment. - Applied and Environmental Microbiology 67(9): 4215-4224.

[31] Sheoran, O. P., Tonk, D. S., Kaushik, L. S., Hasija, R. C., Pannu, R. S. (1998): Statistical Software Package for Agricultural Research Workers. Recent Advances in information theory, Statistics \& Computer Applications by D.S. Hooda \& R.C. Hasija Department of Mathematics Statistics, CCS HAU, Hisar (139-143).

[32] Sihi, D., Dari, B., Dinesh, K., Sharma, H. P., Nain, L., Sharma, O. P. (2017): Evaluation of soil health in organic vs. conventional farming of basmati rice in North India. - J. Plant Nutr. Soil Sci. 2: 1-18.

[33] Srivastava, S. C., Singh, J. S. (1989): Effect of cultivationon microbial biomass C and N on dry tropical forest. - Biology and Fertility of Soils 8: 343-348.

[34] Sunita (2015): Effect of organic farming on quality of soil under rice cultivation. - Journal of Agroecology and Natural Resource Management 2(5): 391-393.

[35] Tabatabai, M. A., Bremner, J. M. (1969): Use of p-nitrophenyl phosphate for assay of soil phosphatase activity. - Soil Biology \& Biochemistry 1: 301-307.

[36] Tamilselvi, S. M., Chinnadurai, C., Hamuruga, K., Arulmozhiselvan, K., Balachandran, D. (2015): Effect of long-term nutrient management on biological and biochemical properties of semi-arid tropical Alfisol during maize crop development stages. - Ecological Indicators 48: 76-87.

[37] Van, G. M., Merckx, R., Vlassak, K. (1996): Spatial distribution of microbial biomass in microaggregates of a silty-loam soil and the relation with the resistance of microorganisms to soil drying. - Soil Biology \& Biochemistry 28(4-5): 503-510.

[38] Vance, E. D., Brookes, P. C., Jenkinson, D. S. (1987): An extraction method for measuring soil microbial biomass C. - Soil Biology \& Biochemistry 19(6): 703-707.

[39] Velmourougane, K. (2016): Impact of organic and conventional systems of coffee farming on soil properties and culturable microbial diversity. - Scientifica, 1-9.

[40] Wada, S. Toyota, K. (2007): Repeated applications of farmyard manure enhance resistance and resilience of soil biological functions against soil disinfection. - Biol. Fertil. Soils 43: 349-356.

[41] Wardle D. A., Yeates, G. W., Nicholson, K. S., Bonner, K. I., Watson, R. N. (1999): Response of soil microbial dynamics, activity and plant litter decomposition to agricultural intensification over a seven-year period. - Soil Biology \& Biochemistry 31: 1707-1720.

[42] Wu, T., Chellemi, D., Graham, J., Martin, K., Rosskop, E. (2008): Comparison of soil bacterial communities under diverse agricultural land management and crop production practices. - Microbial Ecology 55: 293-310.

[43] Yang, Y. H., Yao, J., Hu, S. (2000): Effects of agricultural chemicals on DNA sequence diversity of soil microbial community: A study with RAPD marker. - Microbial Ecology 39: 72-79.

[44] Zhang, P., Zheng, J., Pan, G., Zhang, X., Li, L., Rolf, T. (2007): Changes in microbial community structure and function within particle size fractions of a paddy soil under different long-term fertilization treatments from the Tai Lake region, China. Colloids and Surfaces: Biointerfaces 58(2): 264-270. 